\title{
pÿTropical stream diatom communities the importance of headwater streams for regional diversity
}

\section{Jyrkänkallio-Mikkola, Jenny}

2018

Jyrkänkallio-Mikkola , J , Siljander , M , Heikinheimo , V , Pellikka , P \& Soininen , J 2018 , ' pÿTropical stream diatom communities the importance of headwater streams for regional diversity ' , Ecological Indicators, vol. 95 , no. 1 , pp. 183-193 . https://doi.org/10.1016/j.ecolind.2018.07.030

http://hdl.handle.net/10138/317924

https://doi.org/10.1016/j.ecolind.2018.07.030

cc_by_nc_nd

acceptedVersion

Downloaded from Helda, University of Helsinki institutional repository.

This is an electronic reprint of the original article.

This reprint may differ from the original in pagination and typographic detail.

Please cite the original version. 

*For correspondence. 


\section{Abstract}

Understanding how species are distributed in space and time is a focal element guiding conservational efforts under the ongoing climate change and Holocene extinction. Freshwater habitats are currently one of the most threatened ecosystem types and studies aiming to unravel factors that govern biodiversity of tropical stream micro-organisms are especially scarce. Diatoms play an important role as primary producers in streams and are widely used as ecological indicators. Yet, relatively little is known about which factors affect diatom communities in the tropics.

Here, we studied benthic diatom diversity across 67 tropical streams spanning stream orders $1-5$ in Kenya. We examined whether the hypothesis of latitudinal diversity gradient applies for benthic diatoms, i.e. do tropical streams encompass more species than boreal streams using comparable boreal dataset. In addition, we studied which environmental, land use and spatial factors control benthic diatom communities using redundancy analysis. We also examined the nestedness and turnover components of beta diversity, factors contributing to diatom species richness and the uniqueness of the communities across stream orders by using boosted regression trees and local contribution to beta diversity. Finally, we studied whether environmental heterogeneity and beta diversity are related across stream orders and tested their relationship using tests of homogeneity of dispersion and regression analysis.

Species richness was not higher in tropical streams than in boreal ones. Tropical diatom communities were controlled jointly by local environmental and spatial factors. Although water chemistry was the most important controlling factor, also physical variables contributed significantly to community variation. Land use had also a significant effect on diatom communities as broad leaved forest streams harboured different diatom communities compared to streams with higher human impact and conductivity, stressing the importance of forests to water quality and diatom biodiversity. Headwater streams encompassed highest species turnover, whereas nestedness was higher in higher order 
streams. Species richness was significantly higher in higher order streams than in headwaters, whereas the uniqueness of the communities peaked in headwaters. Environmental heterogeneity was the highest in headwater streams and was related with high beta diversity, which highlights the importance of habitat heterogeneity to biodiversity. Our results stress the management and conservational importance of headwater streams and tropical montane forests as these environments harbour unique diatom communities important for regional diversity.

Keywords: beta diversity, community structure, diatoms, environmental heterogeneity, headwaters, tropics 5

\section{Introduction}

How species are distributed across Earth in space and time remains a fundamental topic guiding conservation efforts under the ongoing climate change and Holocene extinction (Pimm et al., 1995;

Thomas et al., 2004). Extinction threat concerns not only terrestrial ecosystems but also aquatic communities. Freshwater habitats harbour disproportionally large species richness in relation to habitat area in many taxonomic groups and freshwater biodiversity is more threatened than biodiversity in other ecosystems (IUCN, 2009; Strayer and Dudgeon, 2010; Wiens, 2016). Thus, understanding of the drivers that maintain species diversity is urgently needed in order to combat severe biodiversity losses taking place at present.

While studies aiming to unravel the determinants of macro-organismal biodiversity have been extensive (Rosenzweig, 1995), microbial communities (e.g. bacteria, unicellular algae and fungi) have received less attention in this regard (Green et al., 2004; Zeglin, 2015). For example, whereas 
latitudinal diversity gradients are well documented for macro-organisms (Gaston, 2000; Hillebrand, 2004; Lawton, 1999), the existence of such pattern for micro-organisms remains a controversial issue (Hillebrand and Azovsky, 2001; Passy, 2010; Salinas et al., 2015). Furthermore, microbial biodiversity studies in boreal and temperate regions have been far more numerous than in the tropics but see for example (Bellinger et al., 2006; Bere, 2014; Bojorge-Garcia et al., 2014; Mangadze et al., 2015).

The diversity and composition of microbial communities are affected by a wide range of determinants and there is still no consensus whether the key drivers are more related to the local environment (Gothe et al., 2013; Maloufi et al., 2016) or spatial factors (Crump et al., 2007; Soininen et al., 2004). Also land use (Bere and Tundisi, 2011; Carpenter and Waite, 2000) or climatic factors (Pajunen et al., 2016) may affect aquatic microbial communities. Finally, spatial scale of the study influences the factors which govern microbial communities (Lindstrom and Langenheder, 2012) and communities may thus often be described by the shared influence of spatial and environmental factors with increasing spatial influence in larger studies (Heino et al., 2014; Soininen et al., 2016; Verleyen et al., 2009).

Freshwater organisms may be especially vulnerable to changes in precipitation and possible droughts can quickly alter the freshwater habitat and thus their biodiversity (Wiens, 2016). Streams encompass disproportionately high biodiversity (Vinson and Hawkins, 1998; Vorosmarty et al., 2010) and stream network provides an excellent environment to study diversity patterns via its hierarchic dendritic organization (Grant et al., 2007). River Continuum Concept (RCC) predicts biological diversity to peak at mid-order streams, whereas headwaters and large rivers should be less diverse (Vannote, 1980). However, while this prediction might hold true for alpha (local) diversity, beta (between-site) and gamma (regional) diversity may show different patterns as especially headwater streams (orders 1-2) may harbour a great proportion of biodiversity compared to higher order stream branches (Meyer et al., 2007). Moreover, human induced disturbances usually increase with increasing stream order 
83 (Januchowski-Hartley et al., 2011), which may affect biodiversity. Headwater streams may also be more physically variable promoting environmental heterogeneity and subsequently also beta diversity (Finn et al., 2011). Consequently, possible environmental homogenisation in higher order streams may decrease beta diversity compared to headwaters.

High beta diversity in headwaters may also be caused partly by the more isolated position of headwater streams compared to higher order branches (Finn et al., 2011). Thus, highly connected sites at lower reaches harbour lower beta diversity due to higher exchange of individuals between sites leading to homogenisation of communities (Lopes et al., 2014). Furthermore, anthropogenic and natural stressors may cause different patterns to beta diversity given that beta diversity under natural disturbances may be caused more by species turnover (i.e. the shared number of species between sites is small), whereas community dissimilarities under anthropogenic stressors may be more generated by nestedness (i.e. poorer assemblages are subsets of those of richer sites) (Gutierrez-Canovas et al., 2013). These patterns are largely unresolved in tropics, however, as stream beta diversity has not been studied extensively in tropical regions (but see (Al-Shami et al., 2013; Tonkin et al., 2016) and microbial communities have received even less attention.

Sub-Saharan Africa is going through an intense land cover change due to human population growth and subsequent cuts of forests into arable land (Brink et al., 2014; Pellikka et al. 2017a). Land cover changes can have severe effects to the environment and natural resources (Alcantara-Ayala et al., 2006; Hohenthal et al., 2015). Furthermore, land use changes in the catchments may have profound effects also on aquatic ecosystems via water scarcity, increased turbidity and nutrient fluxes (Allan and Castillo, 2007; Hohenthal et al., 2015; Soininen et al., 2015). Human impact on stream communities usually grow downstream, agricultural effects causing the most severe threat to biodiversity (US - Environmental Protection Agency, 2000; Vorosmarty et al., 2010). The detrimental anthropogenic effects are increased by the poor waste water treatment in many rural areas (Concoran 
et al., 2010). Indeed, freshwater biodiversity conservation under the increasing human demands of water poses a true challenge (UNESCO, 2009; Wiens, 2016; Vorosmarty et al., 2010).

Benthic diatoms are a pivotal component of stream biodiversity and are widely used as ecological indicators (Hill et al., 2000; Wang et al., 2005). We studied the diversity and composition of stream benthic diatom communities in Taita Hills, Kenya. The area is considered as a biodiversity hotspot with a high rate of endemism of plants (Beentje and Ndiang'ui, 1988; Gereau et al., 2006; Lovett and Wasser, 1993) and animals (Gereau et al., 2006). At the same time, however, the area is affected by intensive land use change along with other anthropogenic pressures threatening ecosystems and their functioning (Pellikka et al., 2013; Pellikka et al., 2009). First $\left(\mathrm{Q}_{1}\right)$, we were interested if there are major richness differences between tropical and boreal stream diatoms. We thus compared diatom species richness between tropical and boreal streams using two data sets with identical sampling methods. We expected that species richness is higher in tropics as found for other taxa (Hillebrand, 2004). Second $\left(\mathrm{Q}_{2}\right)$, we studied the effects of local environmental, land use and spatial factors on tropical stream diatom community composition. We expected water chemistry and stream physical variables to have a significant effect on diatom composition (Soininen, 2007) but also that communities are spatially structured (Piano et al., 2017). In addition, we expected land use to affect diatom communities indirectly via affecting water quality (Bere and Tundisi, 2011; Carpenter and Waite, 2000; Potapova and Charles, 2002). We considered the use of the diatoms and their diversity as ecological indicators of land cover change by sampling diatoms in four massifs of the Taita Hills of Kenya, which differ in their land use history, but are similar in their bedrock, soil types, forest species composition, agricultural crop composition and climate. Thirdly $\left(\mathrm{Q}_{3}\right)$, we studied the distribution of diatom biodiversity across stream orders. We expected headwater sites (orders 1-2) to harbour more unique diatom communities, and simultaneously, to have lower species richness than higher stream order sites (Meyer et al., 2007; Sherwood et al., 2000). We also examined beta diversity components, i.e., species turnover and nestedness across stream orders and expected species turnover 
132

133

134

135

to be largest in headwaters while nestedness to be largest in downstream sites. Fourthly $\left(\mathrm{Q}_{4}\right)$, we examined factors contributing to diatom species richness and the uniqueness of the communities. We expected that species richness is mostly related to conductivity (Heino et al., 2010) and $\mathrm{pH}$ (Jyrkänkallio-Mikkola et al., 2017) whereas uniqueness would be most related to conductivity and nutrient levels (Pajunen et al., 2017). Finally (Q5), we studied whether environmental heterogeneity and diatom beta diversity are related across stream orders and tested their relationship. We expected headwater streams to harbour higher beta diversity and environmental heterogeneity (Finn et al., 2011; Meyer et al., 2007) than sites at higher order streams.

In this study, we characterized diatom communities using species richness, community composition and the uniqueness of species composition at sites, measured as local contribution to beta diversity

(LCBD; (Legendre and De Caceres, 2013). Since beta diversity provides the most useful measure to understand the processes that generate and maintain biodiversity (Legendre et al., 2005; Qiao et al., 2015; Socolar et al., 2016) we placed most emphasis on beta (between site) diversity in terms of dissimilarities and local contribution to beta diversity.

\section{Material and methods}

\subsection{Study area}

Taita Hills is the northernmost part of the biodiversity hotspot Eastern Arc located in southeastern Kenya rising in the middle of plains to hilltops over $2000 \mathrm{~m}$ of an altitude (Platts et al., 2011). Taita Hills can be separated to Dabida massif, Mbololo massif, Sagala Hill and Mt. Kasigau, which are within $40 \mathrm{~km}$ from each other. The mean elevation of Dabida is between 1300 to $1600 \mathrm{~m}$ a.s.1., the highest peaks reaching over $2000 \mathrm{~m}$ a.s.1. Mbololo massif reaching $1800 \mathrm{~m}$ is located east from Dabida separated by Paranga valley at $900 \mathrm{~m}$ a.s.l. Sagala Hill reaching $1500 \mathrm{~m}$ a.s.l. is located 15 $\mathrm{km}$ southeast from Dabida and Mbololo, and Mt. Kasigau reaching $1600 \mathrm{~m}$ a.s.l. at $40 \mathrm{~km}$ southeast 
156 from Dabida (Fig. 1). Located in the intertropical convergence zone Taita Hills face bimodal rain 157 pattern having rainy season in November-December and in March-May. Annual rainfall in the hills 158 is normally $1200 \mathrm{~mm}$, while the lowlands receive less than $600 \mathrm{~mm}$ per year resulting to rule of the 159 thumb that higher elevations have higher rainfall and are covered more by forests than lower 160 elevations (Erdogan et al., 2011). However, as the rains are orographic in nature, the eastern slopes 161 and hills of Mbololo and Dabida receive more precipitation than the leeward parts and slopes located 162 in the west. A significant addition to the precipitation is occult precipitation, which is estimated to 163 result in $20 \%$ addition to precipitation, but only in the forests as forest volume is required to capture 164 the atmospheric moisture, the mist (Pellikka et al, 2017b). 


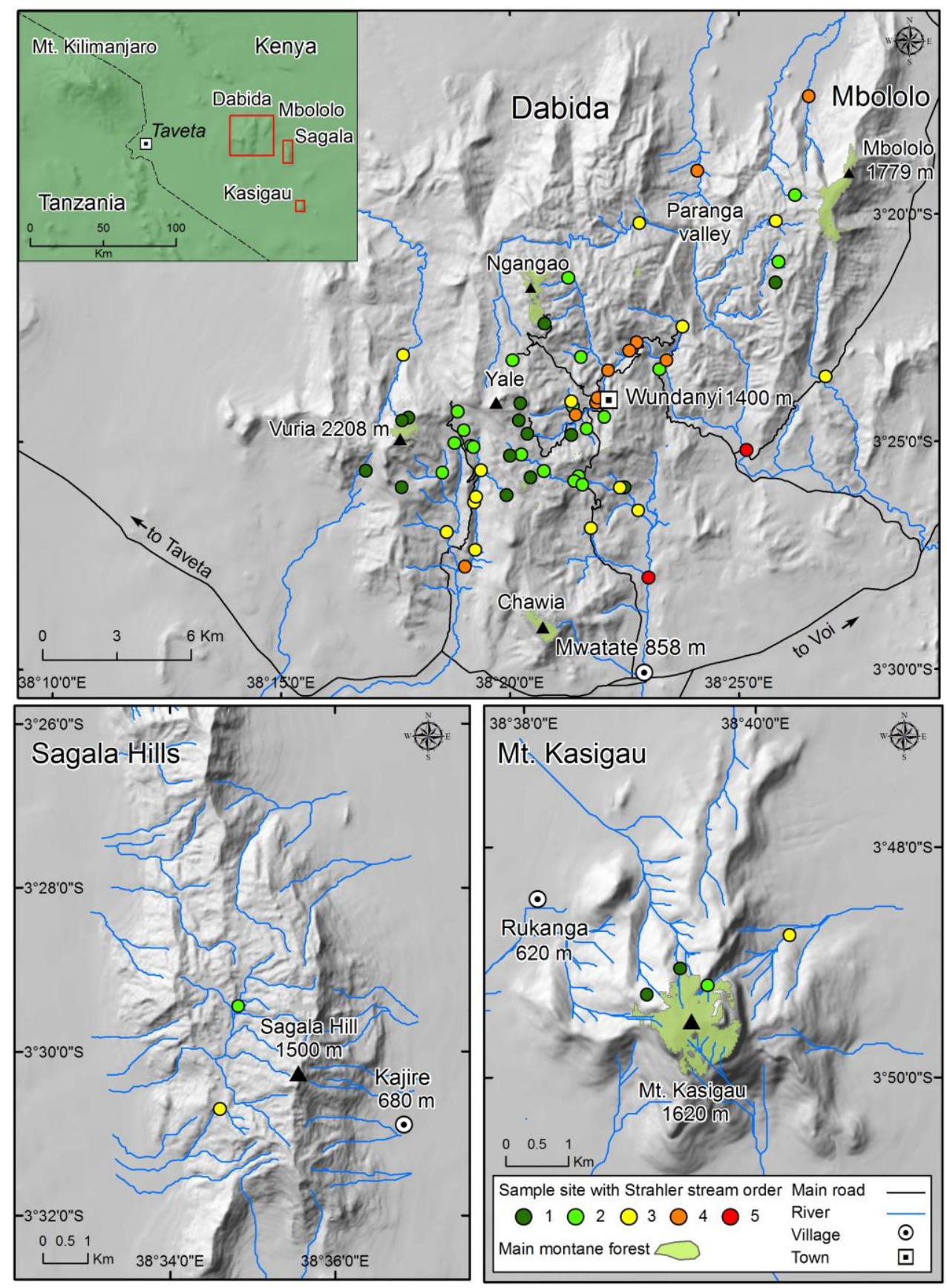

166 Figure 1 Map of the sampling area

167 It is estimated that the hills over approximately $1220 \mathrm{~m}$ a.s.l. prior human disturbance were covered

168 by forests characterized as evergreen moist lower or upper montane forests. Now only a few percent

169 of the montane forests are left mainly as protected forests managed by Kenya Forest Service. Below

$1701220 \mathrm{~m}$ a.s.l. the forests can be characterized as Acacia-Commiphora woodland, which is partly

171 deciduous depending on the species. The hills are cleared for intensive small-scale agriculture the 
main crop being maize producing to harvest per year (Jaetzold and Schmidt, 1987). The lowlands are used for dryland farming, grazing by goats and camels, sisal plantations and conservation areas.

The four massifs studied differ in their land use. Based on Pellikka et al. 2017a, only the hilltops of Dabida and Mbololo massifs are covered by montane forests. Due to cloudy conditions, the peak of Vuria (2208 $\mathrm{m}$ a.s.1.) is characterized as upper montane forest, elfin forest, with trees covered heavily by epiphytes (Stam et al., 2017), while the other native forests are lower montane forests with less epiphytes, but trees reaching up to $40 \mathrm{~m}$ of a height. Over $1220 \mathrm{~m}$ a.s.l. in $241 \mathrm{~km}^{2}$ of an area, croplands cover nowadays $40.4 \%$, montane forests $3.2 \%$ and plantation forests of mainly pine and eucalyptus $10.1 \%$, and woodland, shrubland and thickets all together $44.8 \%$ (Pellikka et al. 2017a). The remaining fragments of montane forests in Dabida and Mbololo massifs are $1-2 \mathrm{~km}^{2}$ in size: Mbololo (185 ha), Ngangao (120 ha), Vuria (ha) and Chawia (86 ha) being the largest ones. These forests are all degraded due to selective timber harvesting and grazing inside of the forest, especially in Vuria and Chawia. The least degraded is Mbololo forest and then Ngangao (Omoro et al., 2013).

Sagala hill has no native montane forests left, but has some plantation forests and degraded woodlands. The montane forest of Mt. Kasigau can be characterized as upper montane forest over $1500 \mathrm{~m}$ a.s.1. due to misty conditions producing fog deposit, and lower montane forest down to 1000 m a.s.l. (Medley and Maingi, 2014) below which dryland forest like Acacia-Commiphora with Euphorbia ssp. takes place. The montane forest of Kasigau is least disturbed of all the forests of the Taita Hills being $2.03 \mathrm{~km}^{2}$ in size (Medley and Maingi, 2014). Croplands did exist in Mt. Kasigau few decades ago, but were abandoned in order to safeguard water resources (Rikkinen et al., 2015). Evidently due to very steep slopes they were also difficult to manage (Adhikari et al. submitted).

\subsection{Biological data collection}


195 Diatom samples were collected at 67 sites from all four mountain massifs (Fig.1). Sampling was completed in three weeks in January 2016. Diatoms were sampled by randomly selecting and brushing 10 cobble-sized stones or bedrock. The samples were collected from different part of the stream site in order to control small-scale variability in the community composition. To standardize the sampling area we used a $5 \times 5 \mathrm{~cm}$ rubber template. The samples were preserved with $99 \%$ ethanol and stored at $+4{ }^{\circ} \mathrm{C}$. Wet combustion with hydrogen peroxide $\left(20 \%, \mathrm{H}_{2} \mathrm{O}_{2}\right)$ was used to clean diatom frustules from organic material. Subsequently, samples were mounted on microscope slides using high-refractive mounting resin Naphrax. We counted and identified at least 500 frustules from each sample using phase contrast light microscope with $1000 \times$ magnification. Species identification was based on Krammer and Lange-Bertalot (1986-1991) and Taylor et al. (2007).

\subsection{Chemical and physical measurements}

Water samples for total nitrogen, total phosphorus and water colour were collected a few meters upstream from each sampling site. Total nitrogen was determined by using alkaline persulfate digestion where alkaline oxidation is carried out in a thermo digester and the converted total nitrogen quantified colorimetrically. Total phosphorus was determined by inductively coupled plasma-optical emission spectrometry (ICP-OES). However, as the method lacked the sensitivity to determine phosphorus concentrations below $10 \mu \mathrm{g} \mathrm{L}^{-1}$ and the phosphorus content of 51 samples were $\leq 10 \mu \mathrm{g}$ $\mathrm{L}^{-1}$ we were unable to use total phosphorus in the following analyses. Water colour was analysed using standardized method (EN ISO7997).

To measure conductivity, $\mathrm{pH}$ and temperature in the field we used YSI professional plus water quality meter (YSI Incorporated, Yellow Springs, USA). Current velocity was measured with Schiltknecht MiniAir 2 flow meter (Schiltknecht, Gossau, Switzerland) from 30 locations covering the sampling 
218 site extensively. Water depth was similarly measured from 30 locations and stream width from 10 219 locations covering the length of the whole sampling site.

220 Substratum particle size was measured from 10 locations using a $50 \times 50 \mathrm{~cm}$ quadrat placed in random 221 sites on the streambed. We used a modified Wentworth scale to visually classify the substratum 222 particle size: sand (diameter $0.25 \mathrm{~mm}-2 \mathrm{~mm})$, gravel $(2 \mathrm{~mm}-16 \mathrm{~mm})$, pebble $(16 \mathrm{~mm}-64 \mathrm{~mm})$, 223 cobble $(64 \mathrm{~mm}-256 \mathrm{~mm})$ and boulder $(>256 \mathrm{~mm})$ (Wentworth, 1922). Canopy shading was 224 individually estimated from 20 locations covering the whole sampling site. Range and average values 225 of measured environmental variables are listed in Appendix A in the supplementary material.

\subsection{Stream order analyses and land cover data}

River network and stream ordering were calculated from Digital Elevation Model (DEM) data. DEM of $1 \times 1 \mathrm{~m}$ resolution was derived from airborne laser scanning (ALS) data sets for two parts of the study area (Taita Hills and Kasigau). Laser scanning data was acquired in 2013 and 2014 (using Optech ALTM 3100), and data was filtered for buildings, powerlines and outliers using Terrascan software (Terrasolid Oy), LasTools (Rapidlasso GmbH) and manual editing. For Sagala area, a DEM was created from scanned Survey of Kenya 1:50 000 scale topographic map from which the contour lines were digitized and converted to $10 \mathrm{~m}$ resolution raster DEM.

Watershed delineation was based on the DEM layers and, hydrological modelling tools in ArcGIS 10.3.1. Firstly, elevation grids were filled to create a surface that has no sinks. Then, flow direction grid was calculated to determine the direction of flow for each cell in the landscape. Flow accumulation function was used to generate a drainage network for the selected pour points. The Snap Pour Point tool was used to ensure selection of points of high accumulated flow and finally, watersheds were automatically delineated. ArcGIS 10.3.1 hydrological tools and Stream Order 
networks. Elevation models were harmonized by resampling the DEM layers into $10 \mathrm{~m}$ pixel size. River networks were then determined again and stream ordering calculated.

Land cover was assessed from classifies satellite imagery separately for Taita Hills, Kasigau and Sagala. For Taita Hills, the land cover classification was based on a $20 \times 20 \mathrm{~m}$ resolution SPOT 4 satellite image from 23 October 2011 (CNES, 2013). The satellite image was classified into 9 land cover classes (Pellikka et al., 2017; Appendix A in the supplementary material) using an object-based approach (Benz et al., 2004) following the methodology presented in Clark and Pellikka (2009). Segmentation and classification was implemented in the eCognition software (Trimble). After manual corrections, the overall accuracy of the land cover map was $71.1 \%$ when comparing the map with 305 random ground-truth points.

For Sagala area, Sentinel-2A MSI Level-1C satellite image from 8 October 2016, downloaded from the Sentinel's Scientific DataHub (ESA, 2015) and RandomForest (Breiman, 2001) classifier in R software were used to create the land cover classification. Firstly, Sentinel-2A was DOS1 atmospheric corrected using Semi-Automatic Classification Plugin in QGIS. Then, classifier training areas were on-screen digitized from very high-resolution ( $1 \mathrm{~m}$ pixel size) image mosaic from 2004 and from more up to date satellite imagery (Google Earth, 2016). Then, reflectance values from the four bands blue, green, red and infra-red from the Sentinel 2A satellite image were used as the predictors for RandomForest classifier. The image was classified to the following relevant classes: bush, fields, forest and impervious.

For the Kasigau area, information from the same Sentinel 2A satellite image was combined with canopy height model (CHM) and DEM derived from the ALS data for creating the land cover classification map. First, the CHM was reclassified to 5 elevation classes in ArcGIS 10.3.1. NDVI (normalized difference vegetation index) values derived from the Sentinel-2A satellite image were used to separate non-vegetated areas from different type of green areas. Then, Kasigau study area was classified into highland and lowland zones based on the $1 \mathrm{~m}$ pixel size DEM to separate montane 
vegetation from lowland vegetation after which ArcGIS Map Algebra tool was used to derive land cover classes listed in Appendix A in the supplementary material. The resulting land cover map was evaluated using GPS field measurements, very high resolution airborne imagery ( $1 \mathrm{~m}$ pixel size) and also the previous knowledge of the area. Prior to statistical analyses, the land cover classes of the 6 sampling sites from Sagala and Kasigau were equated with those classified from Taita Hills. Finally, zonal statistics of the percentages of land use and land cover classes were calculated for different watershed areas based on the land cover layers and delineated watersheds for the whole study region.

\subsection{Statistical analyses}

Prior to analyses, explanatory variables measured as percentages were arcsine-transformed while other explanatory variables were log-transformed. In addition, diatom abundance data were Hellinger transformed to better meet the requirements of linear ordination methods (Legendre and Gallagher, 2001). Correlations between explanatory variables were tested using Pearson correlation. As none of the correlations exceeded 0.70 , we kept all the explanatory variables in the subsequent models (Dormann et al., 2013).

Failure to notice spatial autocorrelation can lead to false interpretations of environmental variables' effects on community composition. Thus, spatial autocorrelation of the local environmental variables and species richness was tested using function correlog in the R package 'pgirmess' (Giraudoux, 2015). The significance of the correlogram was tested at level $P \leq 0.05$ with applied Bonferroni correction $(\mathrm{P} / \mathrm{k}$, where $\mathrm{k}$ is the number of distance classes used). Here, distance class of $7 \mathrm{~km}$ was used as it was most suitable for the spatial distances in our data.

To test whether more species are found from the tropics than boreal areas $\left(\mathrm{Q}_{1}\right)$, species accumulation curves (function specaccum in the R package 'vegan'; (Colwell and Coddington, 1994; Palmer, 1990)) were used. The used boreal stream diatom data are explained in detail in Jyrkänkallio-Mikkola 
291

et al. (2017). To standardize the number of sampling sites, 67 samples from the boreal data originally comprising 105 sites were chosen. First order Jackknife method was used to estimate the total species richness for both biomes.

To model spatial structures among tropical study sites, distance-based Moran’s eigenvector maps (dbMEM) derived from spatial coordinates (function dbmem in the R package 'adespatial'; (Dray et al., 2017)) were used. Threshold value was calculated using function give.thresh. Only eigenvectors with positive autocorrelation were used to model spatial effects in subsequent analyses.

Redundancy Analysis (RDA) was applied to study community structure (abundance data)environment (excluding land use) relationships $\left(\mathrm{Q}_{2}\right)$ for the whole tropical dataset (Legendre and Legendre, 2012). Another RDA was conducted exclusively for 39 independent sites (i.e., sites that had independent catchments) to examine the effects of land use and catchment size on the diatom communities. Stepwise model (forward selection) with 200 permutations was used to create final RDA models (function ordiR2step in the R package 'vegan'; (Oksanen et al., (2015)).

Distribution of biodiversity across stream orders $\left(\mathrm{Q}_{3}\right)$ was studied with a set of analyses. To study the uniqueness of diatom community composition across sites, local contribution to beta diversity (LCBD) was calculated for each site (function beta.div in the R package 'adespatial'; (Legendre and De Caceres, 2013)). The analysis was based on abundance data for which Hellinger dissimilarity coefficient was applied and the analysis was run with 999 permutations. Linear regression was applied to study the relationship between species richness and LCBD across sites and how richness and LCBD varied across stream orders. To study whether different dissimilarity components govern diatom beta diversity across stream orders, species turnover, nestedness and total beta diversity were calculated for two groups of stream orders, 1-2 and 3-5, respectively (function beta.multi in the R package 'betapart' (Baselga et al., 2017)). 
314 To explain variation in species richness and LCBD using environmental variables $\left(\mathrm{Q}_{4}\right)$, boosted 315 regression trees (BRT; function gbm in R package 'gbm', (Elith et al., 2008)) were used. Tree 316 complexity was set to 3 , learning rate to 0.001 and bagging fraction to 0.75 . The benefits of this 317 machine learning technique include, that it can be run with raw values, it takes into account 318 interactions between predictors and has small prediction errors (Elith et al., 2008).

319 Test of homogeneity of dispersion (PERMDISP, function betadisper in the R package 'vegan' 320 (Anderson, 2006; Anderson et al., 2006)) was applied to relate environmental heterogeneity (habitat 321 variables) within stream orders with corresponding variation in diatom community composition $\left(\mathrm{Q}_{5}\right)$. 322 Sørensen coefficient was used for presence-absence data and Euclidean distances were applied for 323 standardized habitat variables. PERMDISP tests among group differences from individual 324 observation to their group centroid using ANOVA F-statistics (Anderson et al., 2006). Null 325 hypothesis that there is no difference in diatom beta diversity and environmental heterogeneity among 326 the different stream orders was tested. All tests were run using 999 permutations. Finally, null 327 hypothesis that there is no relationship between the degree of beta diversity and the degree of 328 environmental heterogeneity across the different stream orders was tested using linear regression.

329 Explained variation in RDA and linear regressions were reported using adjusted $\mathrm{R}^{2}$ - values. All 330 analyses were conducted in $\mathrm{R}$ version 3.2.2 ( $\mathrm{R}$ Development Core Team, 2013) using packages 331 'adespatial' (Dray et al., 2017), 'betapart' (Baselga et al., 2017), 'corrplot' (Wei and Simko, 2016), 332 'dismo' (Hijmans, 2015), 'gbm' (Ridgeway, 2013), 'pgirmess' (Giraudoux, 2015) and 'vegan' 333 (Oksanen et al., 2015).

336 Altogether 297 taxa were identified from 67 tropical sites, of which 104 were found from only one 337 site. Local diatom species richness varied from 15 to 71 in the tropical data set. The random selection 
338 of 67 sampling sites from comparative boreal dataset resulted in taxa richness of 303. Species 339 accumulation curves revealed that there was only a minor difference in the proportion of total species 340 richness for boreal $(76.4 \%)$ and tropical $(74.6 \%)$ datasets $\left(\mathrm{Q}_{1}\right.$; Appendix $\mathrm{B}$ in the supplementary 341 material).

342 Out of local environmental variables, only water temperature and stream width showed significant 343 spatial autocorrelation on short distances (Appendix C in the supplementary material). Species 344 richness showed no spatial autocorrelation. dbMEM returned one spatially autocorrelated eigenvector 345 (referred henceforth as MEM1), that was used to model spatial structures among sites in the 346 subsequent RDA and BRT analyses.

347 In the first RDA (67 sites), forward selection method returned seven significant $(P<0.05)$ variables 348 which together explained $15.6 \%$ of the total community variation $\left(\mathrm{Q}_{2}\right.$, Fig.2a). Conductivity and $\mathrm{pH}$ 349 were among the most important variables for diatom composition. Also the physical variables 350 (shading and gravel), spatial (elevation and MEM1) and stream order were among the significant 351 variables structuring the community. The first RDA-axis divided the sites with high conductivity, $\mathrm{pH}$ 352 and high stream order opposite to those with high elevation. The second RDA-axis was mostly related 353 to shading. We further tested whether removing singletons would increase the explained variation in 354 community composition. This resulted only to minor increase (15.9\%) of the explained variation with 355 the same explaining variables. When presence-absence data were used explanatory power decreased 356 to $10.9 \%$. In the second RDA (39 sites) including land use variables, selection method returned four $357(P<0.05)$ significant variables which explained $14.4 \%$ of the total community variation $\left(\mathrm{Q}_{2}\right.$, Fig. 358 2b). The first RDA-axis divided the sites to those with high percent of broad leaved forest and high 359 elevation opposite to those with high conductivity. 

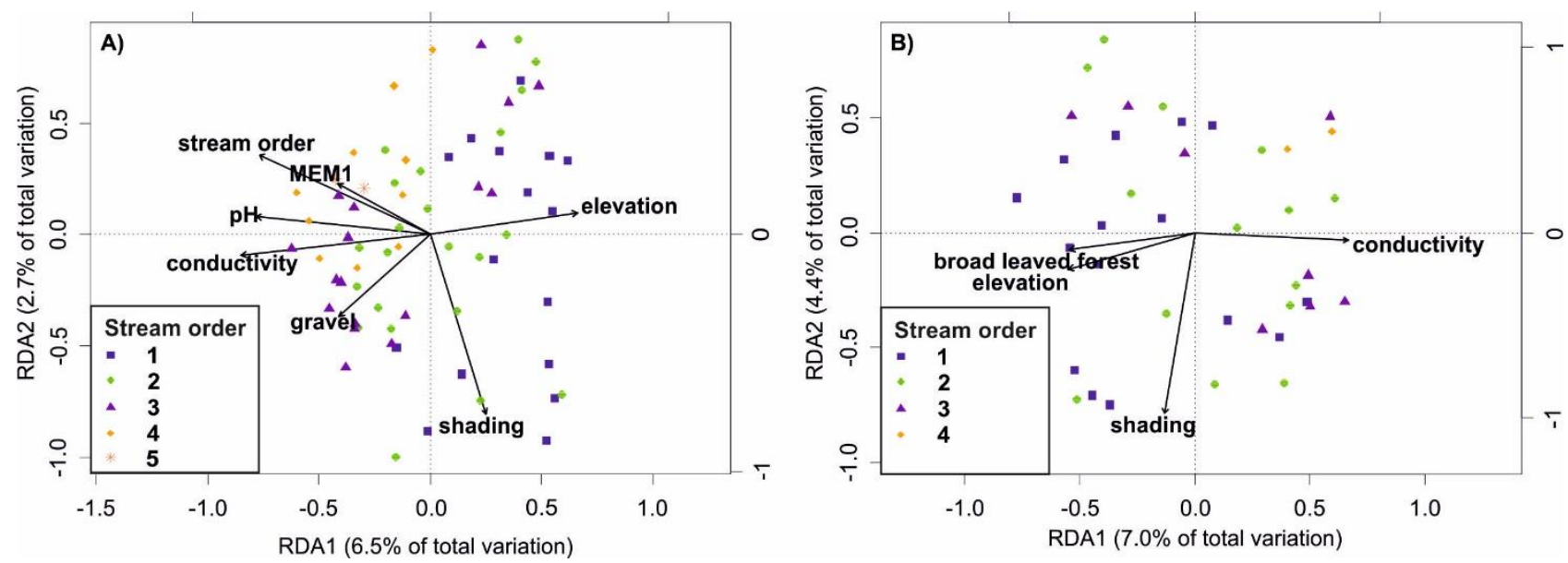

Figure 2 Ordination plots for redundancy analysis for A) all 67 sampling sites and environmental variables and B) for 39 sites with independent catchment areas and environmental and land use variables. Both ordination plots are based on Hellinger transformed diatom abundance data. Arrows represent the significant environmental variables. The explained variation is based on adjusted $\mathrm{R}^{2}$. Abbreviations: MEM1 (spatial eigenvector derived from distance-based Moran's eigenvector maps)

According to linear regression, species richness increased significantly with increasing stream order $\left(\mathrm{Q}_{3}\right.$, Fig.3a, $\left.P<0.001, \mathrm{R}^{2}=0.142\right)$, whereas $\mathrm{LCBD}$ values showed an opposing trend with the highest values in headwater streams $\left(\mathrm{Q}_{3}\right.$, Fig.3b, $\left.P<0.05, \mathrm{R}^{2}=0.053\right)$. LCBD and species richness showed significant negative relationship $\left(\mathrm{Q}_{3}\right.$, Fig. 3c; $\left.P<0.001, \mathrm{R}^{2}=0.425\right)$. Total beta diversity was higher 371 in headwater streams $\left(\mathrm{Q}_{3}\right.$, orders $\left.1-2, \beta_{\text {sor }}=0.933\right)$ than in higher order streams (orders $3-5, \beta_{\text {sor }}=$ 372 0.867). Beta diversity components varied across stream orders. As we expected, species turnover was 373 higher in headwater streams (orders $\left.1-2, \beta_{\text {sim }}=0.905\right)$ than in higher order streams (orders $3-5$, $\beta_{\text {sim }}$ $374=0.860)$, whereas nestedness was lower in headwater streams $\left(\beta_{\text {nes }}=0.027\right)$ than in higher order 375 streams $\left(\beta_{\text {nes }}=0.036\right)$. 

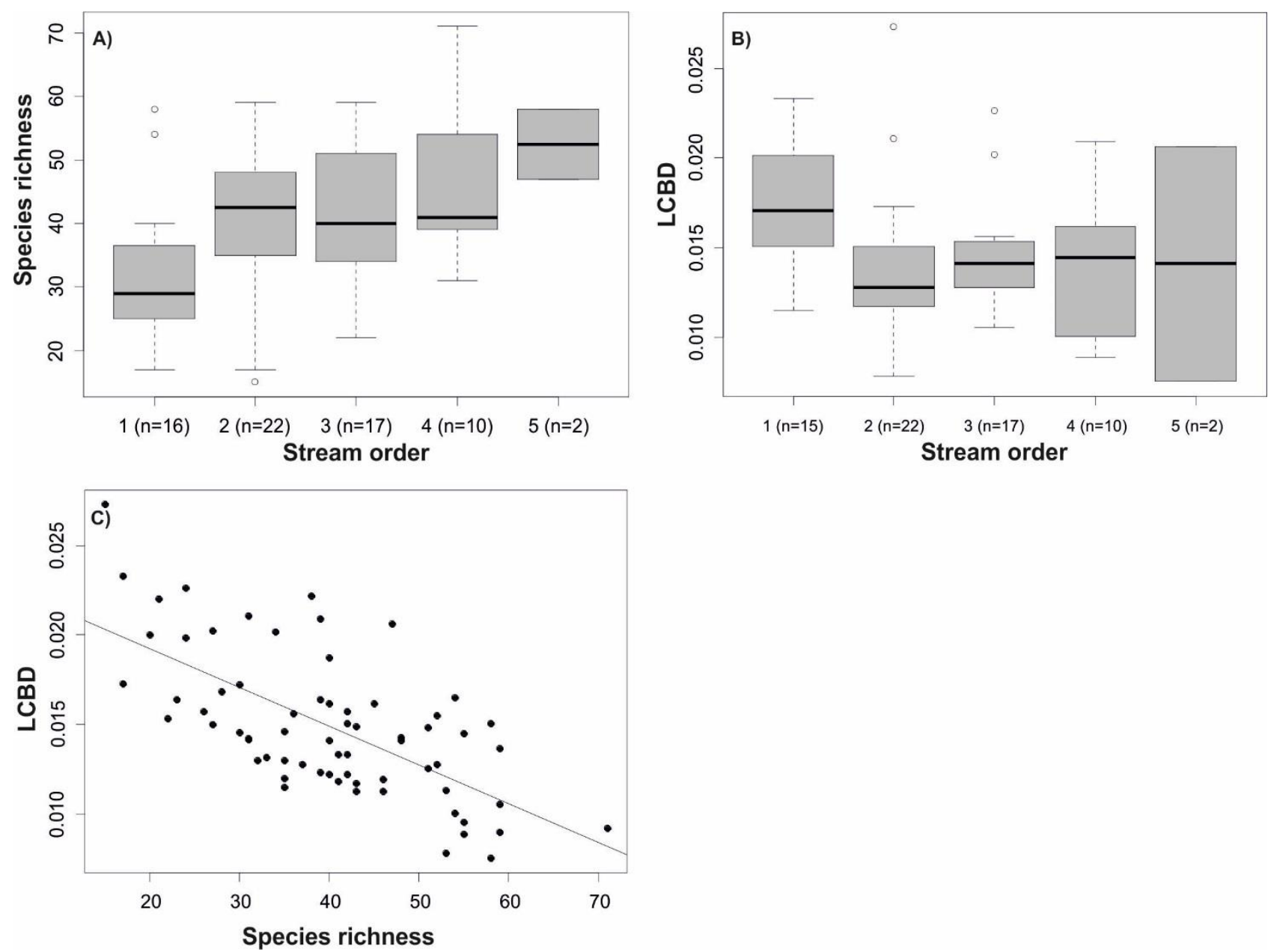

Figure 3 Boxplots representing the relationship between A) species richness and B) LCBD values and stream orders.

Also shown is $\mathrm{C}$ ) the linear relationship between LCBD and species richness. Abbreviations: LCBD (local contribution to beta diversity).

In BRT, the most important factors affecting species richness were $\mathrm{pH}$, temperature, conductivity and spatial variable (MEM1) all of which showed positive relationship with species richness $\left(\mathrm{Q}_{4}, \mathrm{Fig} .4 \mathrm{a}\right)$. Here, we also used polynomial regression and found that the relationship between species richness and temperature was unimodal $\left(P<0.01, \operatorname{Adj} . \mathrm{R}^{2}=0.148\right)$. According to BRT, the most important variables affecting LCBD were conductivity, temperature, water color and stream velocity $\left(\mathrm{Q}_{4}\right.$, Fig.4b). Conductivity, temperature and, $\mathrm{pH}$ were negatively related with LCBD, whereas water color scaled positively with LCBD (Fig. 4b). 
A) Species richness
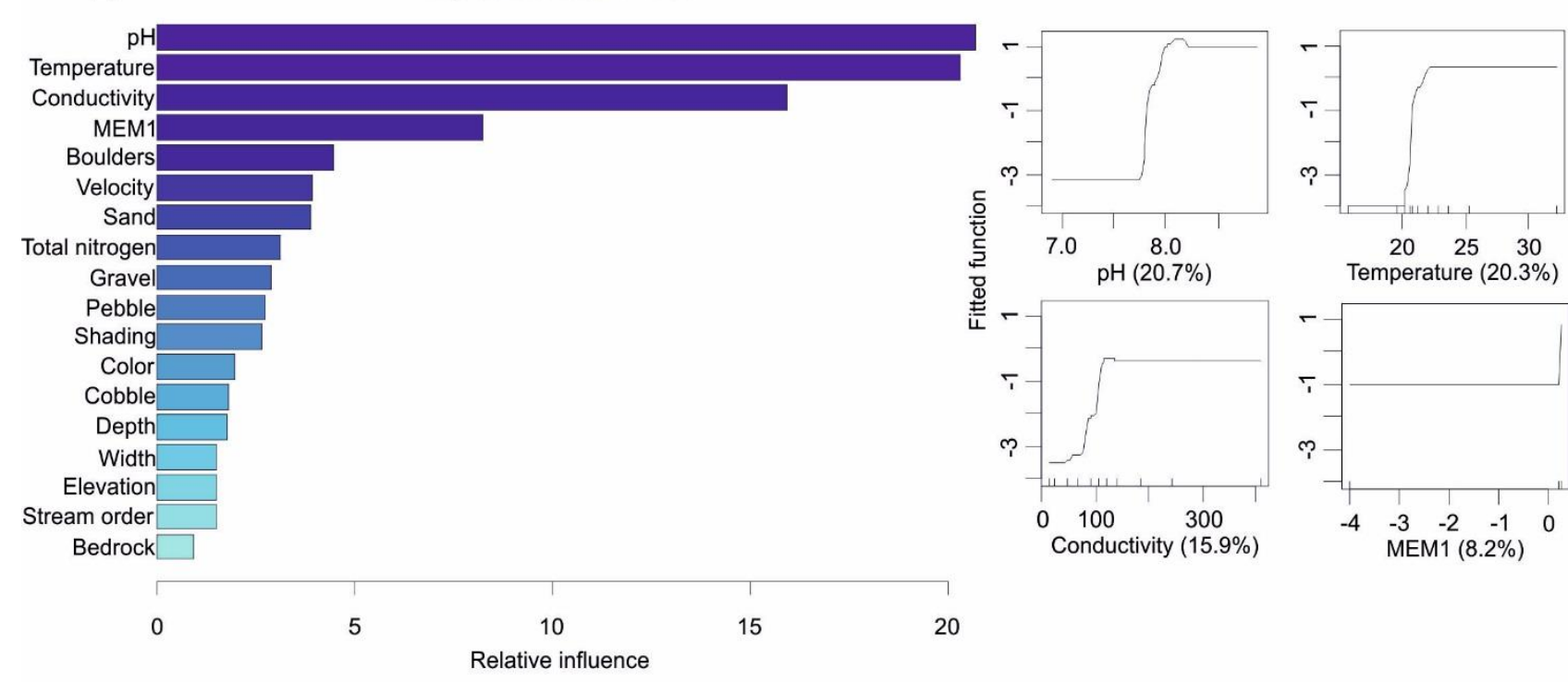

.

\section{LCBD}
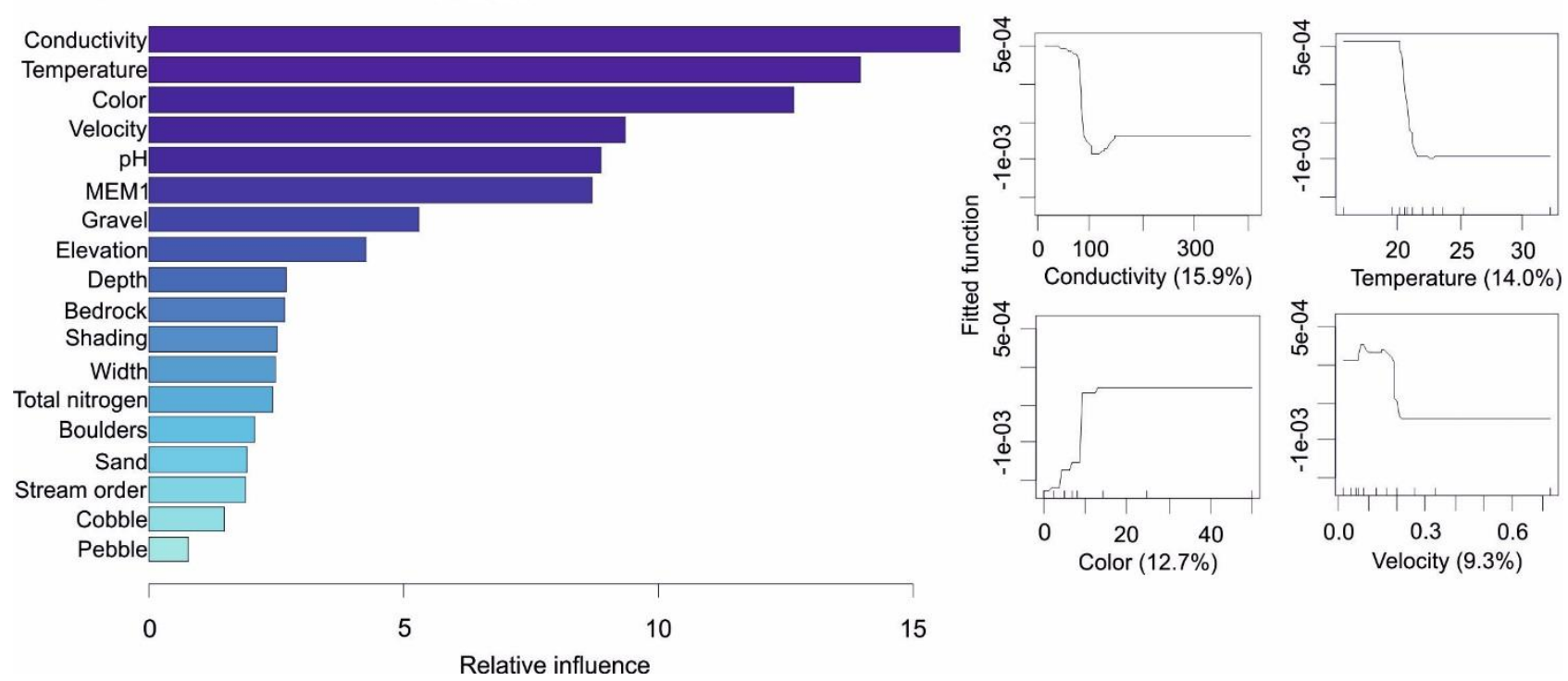

$20 \quad 25 \quad 30$

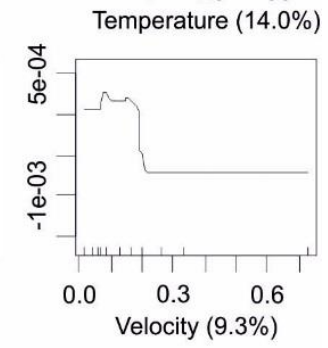

Figure 4 Boosted regression tree summary showing the relative importance of each variable and related fitted function curves for the four most important variables on A) species richness and B) LCBD values. Abbreviations: LCBD (local contribution to beta diversity), MEM1 (spatial eigenvector derived from distance-based Moran's eigenvector maps)

PERMDISP revealed that there were significant differences in the degree of beta diversity $(P<0.01$, $\mathrm{F}=6.55)$ and environmental heterogeneity $(P<0.05, \mathrm{~F}=3.30)$ among the stream orders $\left(\mathrm{Q}_{5}\right.$, Fig.5a, b). Beta diversity and environmental heterogeneity were higher in headstreams than in higher order streams (Q5, Fig.5a, b). Albeit based on only five observations, we found a significant positive 
398 relationship $\left(P<0.05, \mathrm{R}^{2}=0.736\right)$ between the degree of beta diversity and environmental 399 heterogeneity.

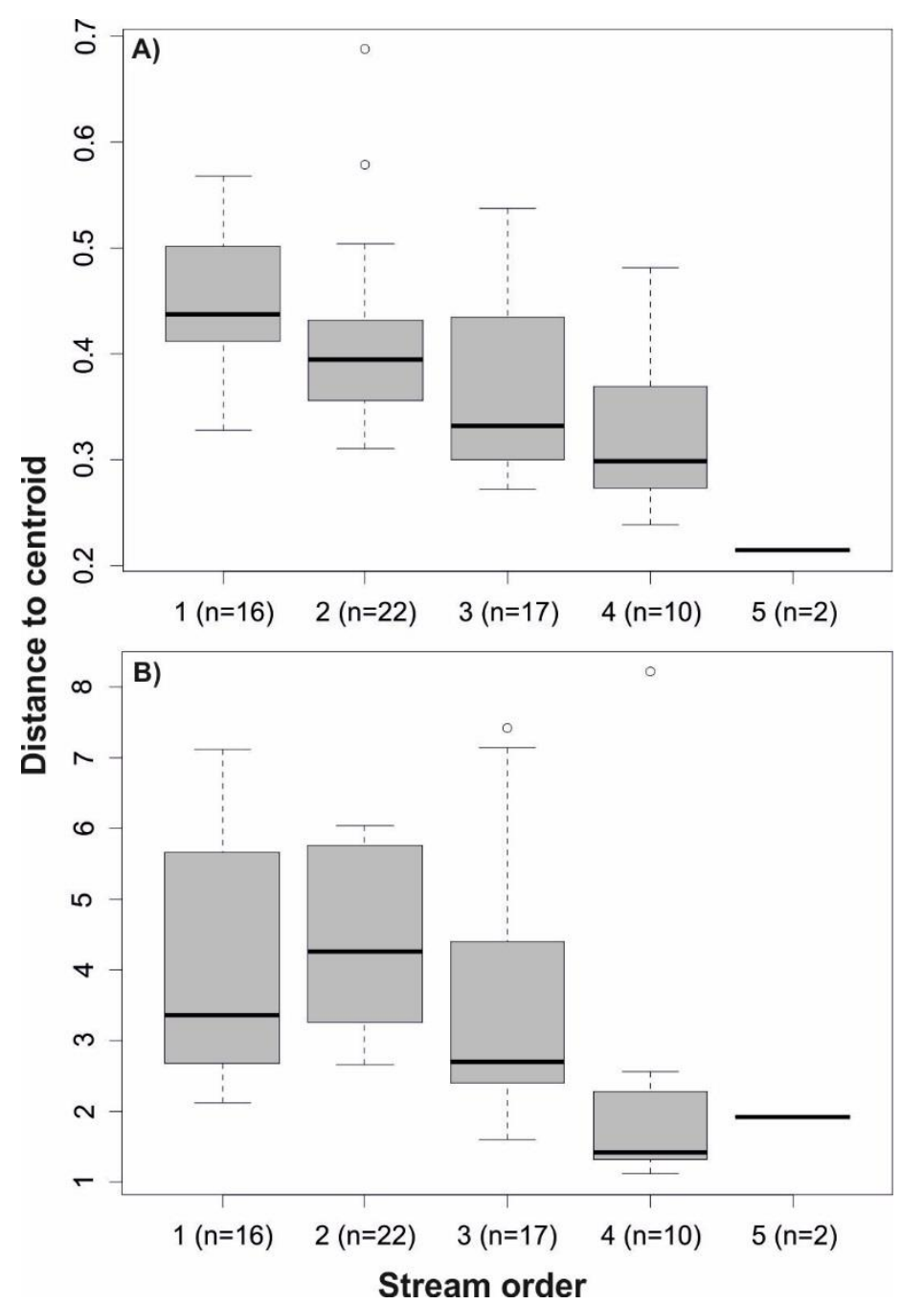

Figure 5 Boxplots representing the relationship of mean distances from group centroids and stream order based on Sørensen dissimilarity (A) and environmental data using Euclidean distance (B).

\section{Discussion}

The tropical studies focusing on diatom community structure, species richness and beta diversity patterns and their underlying processes are still rare compared with the temperate and boreal studies. In addition, diatom diversity patterns along stream networks are also generally relatively poorly understood. Here, our results shed light on the patterns and controlling factors on these important and understudied issues and may be relevant for watershed management and biomonitoring. 
411 Even if largely similar sampling methods and efforts were used, we revealed no clear differences in 412 diatom species richness between tropical and boreal areas. As the sampling area of the boreal dataset 413 was larger than the tropical, and as species richness usually increases with the size of the sampling 414 area, we further tested the difference in species richness between boreal and tropical areas by choosing 415 only the 67 southernmost sites of the boreal dataset in order to have more comparable sampling areas. 416 This approach resulted in total species richness of 298 in boreal data set and the proportion of total 417 species richness on species accumulation curve in $77.9 \%$, which indicates that tropical and boreal 418 streams seem not to differ in diatom species richness. Earlier literature about latitudinal diatom 419 richness patterns have documented very variable richness gradients. Passy (2010) found the 420 relationship of benthic diatom richness and latitude to be U-shaped in a study that comprised running 421 waters of continental U.S.. Highest species richness was found from subtropics and temperate sampling sites and was related with nutrient resources rather than climate. A positive relationship between marine diatom species richness and decreasing latitude was found by Salinas et al. (2015), whereas Hillebrand and Azovsky (2001) found no latitudinal effect for diatom species richness and suggested that latitudinal diversity gradient is determined by body size. Hence, our results add to the controversy of the subject and call for further investigation in different types of ecosystems.

427 Our results are congruent with previous studies suggesting that diatom communities are shaped by 428 both environmental and spatial factors (Gothe et al., 2013; Heino et al., 2012; Heino et al., 2014; Potapova and Charles, 2002; Soininen et al., 2016; Verleyen et al., 2009) indicating both 430 environmental control and dispersal limitation. However, it cannot be excluded that the observed 431 spatial structure here was caused by mass effects (i.e. due to high dispersal rates, a species can be 432 present also in unfavorable sites, (Shmida and Wilson, 1985)) rather than dispersal limitation, due to 433 the relatively small spatial scale (i.e. $<100 \mathrm{~km}$ ) of the study and high connectivity among sites 434 (Astorga et al., 2012). In such conditions, mass effect may be caused by downstream drift of diatom 435 cells (Gothe et al., 2013). 
436 Among local factors, our study highlighted the importance of water $\mathrm{pH}$ and conductivity for diatoms.

437 Conductivity (Astorga et al., 2012; Bere and Tundisi, 2011; Biggs, 1995) and water pH (Bere and 438 Tundisi, 2011; Soininen et al., 2004; Telford et al., 2006) have been repeatedly found to be important 439 controlling factors for diatoms also earlier in wide range of study regions, suggesting that these water 440 chemistry factors are important for diatoms both in tropical and boreal regions. In addition, shading 441 proved to be another important variable structuring diatom communities, a finding, that is further 442 supported by Carpenter and Waite (2000), for example. Thus, although water chemistry plays an 443 indisputable part in structuring diatom communities, it seems that also physical variables may be 444 important, especially light conditions and the substrate of the stream bed. As similar findings emerged 445 in boreal region as well (Jyrkankallio-Mikkola et al., 2016; Jyrkänkallio-Mikkola et al., 2017), the 446 importance of physical variables in structuring diatom communities applies also to the tropics, which 447 could be important to take into account in biomonitoring.

As expected, land use affected diatom communities indirectly through water chemistry and our results suggest that forested high elevation sites including montane cloud forests harbored different diatom communities compared to those found at sites with high conductivity. Similar findings have also been reported by Carpenter and Waite (2000). Thus, including land use variables when unravelling factors controlling the diatom communities may be useful, since this approach provides long-term information of the surrounding habitat in addition to snapshot proximate controlling factors, i.e. water chemistry (Bere and Tundisi, 2011; Jyrkänkallio-Mikkola et al., 2017). This finding also emphasizes the importance of montane cloud forests for regional aquatic diversity, and furthermore their conservational importance in general as they are of great importance to regional tree diversity, for example in the Taita Hills (Aerts et al., 2011; Schafer et al., 2016) and are currently the most threatened and one of the least studied tropical ecosystems (Williams-Linera, 2002).

The low explanatory power of direct ordination analyses such as RDA used here is common in microbial studies (Beisner et al., 2006; Heino et al., 2012; Nabout et al., 2009). This might be related 
461 to some unmeasured environmental variables although we find this explanation unlikely, since 462 probably the most influential factors structuring diatom communities were included in the analyses. 463 However, we admit that the inclusion of phosphorus might have increased the explanatory power of 464 the model. The surprisingly low phosphorus levels observed might be related to the fact that 465 phosphorus is a major limiting nutrient in old tropical soils (Reich and Oleksyn, 2004) and hence the 466 subsequent leach to the streams may be very low. The low explanatory power might also be due to 467 468 469 Langenheder, 2012).

As hypothesized, diatom species richness increased with stream order, which is also supported by previous diatom studies (Sherwood et al., 2000; Stenger-Kovacs et al., 2014). Due to the lack of stream sites above order 5, we cannot rule out the possible decrease in species richness in very large streams and thus, the predicted unimodal pattern of species richness along the river network (RCC theory). However, even if headwater streams harbored lower species richness they comprised more unique communities than higher order stream sites. Headwater streams can be regarded as isolated and less connected habitats compared to downstream sites and hence, the connectivity of the sampling sites may have a strong effect on the community composition via the exchange of individuals (Lopes et al., 2014). High uniqueness of headwater assemblages have also been reported for macroinvertebrates (Finn et al., 2011), fish (Paller, 1994) and biofilm assemblages (Besemer et al., 2013), stressing the conservational importance of headwater streams, contributing strongly to 484 regional gamma and beta diversity. Our results provide evidence that the high uniqueness of 485 headwater communities prevails also in the tropics, perhaps indicating that there are certain general 
rules for predicting biodiversity (Finn et al., 2011). This result is especially important in areas, where major changes in land use occur together with climate change and consequent draughts may deteriorate or even destroy fragile and important ecosystems such as montane forests. We note that our results are in contrast with the RCC view of headwaters harboring communities less important for stream biodiversity and hence, we think that our results are also important for stream ecology in general.

Agreeing with our findings, similar negative pattern between community uniqueness and species richness across sites has also been found in several biomes and for different organisms; tropical Brazil for dung beetles (da Silva and Hernandez, 2014), subtropical China for plants (Qiao et al., 2015), temperate France for phytoplankton (Maloufi et al., 2016) and boreal Sweden for macroinvertebrates (Heino et al., 2017). Although Legendre and De Caceres (2013) point out that this negative relationship is not general or obligatory (see paper supporting this view for bacteria in the Canadian subarctic by (Comte et al., 2016)), it seems to be a relatively common phenomenon at least. Furthermore, this finding suggests that species richness may not be the only or even the best diversity measure for conservational efforts (Dormann et al., 2007), whereas community uniqueness might be in some circumstances more effective in this regard. We thus think that the combination of different metrics would probably be most informative approach in many ecosystems.

Of beta diversity components, species turnover was dominating, whereas nestedness was notably smaller. Similar results have been reported also by Wetzel et al. (2012) and Piano et al. (2017). In our study, it is probable that the high number of singletons contributed to the high turnover rate among sites while richness differences had smaller influence. Total beta diversity and species turnover were higher in headwater streams, whereas nestedness component increased downstream, as we expected. This finding may suggest that the increase of anthropogenic influence downstream changes also the relative effects of mechanisms contributing to beta diversity, thus supporting the results of GutierrezCanovas et al. (2013). Whereas conductivity, temperature and $\mathrm{pH}$ were included into the top five 
most significant variables affecting species richness and LCBD, stream order played a minor role. As BRT takes into account interaction effects between variables, this finding suggests that conductivity, $\mathrm{pH}$ and water temperature were among the proximate factors causing the differences in diatom community composition between stream orders, as all these variables showed significant positive relationship with the stream order (Appendix D in the supplementary material). Thus, this finding is congruent with Stenger-Kovacs et al. (2014) who suggested that the stream order may act as a useful parameter summarizing the physical habitat in streams.

As hypothesized, diatom beta diversity and environmental heterogeneity were higher in headwater streams than in larger stream sites. Thus, our results provided evidence that along with a stronger dispersal limitation in headwaters, environmental heterogeneity may have promoted variation in diatom community composition in headwaters, suggesting that decreasing environmental heterogeneity downstream may at least partly cause subsequent decrease in diatom beta diversity towards larger streams. The higher environmental heterogeneity in headwater streams stresses their conservational importance for regional diversity, which gets support from other studies that have found higher habitat heterogeneity to increase beta diversity for planktonic diatoms (Zorzal-Almeida et al., 2017) and phytoplankton in general (Maloufi et al., 2016). Although we admit that the conservation of microbial organisms may not have as strong research need as conservation of larger taxa, similar results have also been reported for stream macroinvertebrates (Astorga et al., 2014) emphasizing the effect of environmental heterogeneity to regional diversity. Consequently strong emphasis should be placed on headwater stream conservation and management in general.

\section{Conclusions}

Our results indicate that tropical streams do not seem to harbor more diatom species compared to boreal streams. Studies aiming to unravel the determinants of diatom communities are encouraged to 
535 consider spatial, land use and physical variables in addition to water chemistry variables. Land use 536 variables may affect diatom communities indirectly through water chemistry and can provide long 537 term information of the surrounding habitat. Diatom species richness and the uniqueness of the 538 communities may vary across stream orders with headwater sites encompassing more unique 539 communities and higher order streams higher species richness. This results is important to take into 540 consideration in biomonitoring and studies focusing on stream diatom species richness and 541 community composition. Environmental heterogeneity seems to be higher in headwater streams and 542 also relate with the degree of diatom beta diversity and, thus, our results emphasize the management 543 and conservational importance of headwater streams.

\section{Acknowledgements}

546 We thank the Academy of Finland. The study is done under the following projects funded by 547 Academy of Finland: Scaling biodiversity in tropical and boreal streams: implications for diversity 548 mapping and environmental assessment (grant 273560) and TAITAWATER - Integrated land cover549 climate-ecosystem process study for water management in East African highlands, and Finnish 550 Culture Foundation through project Remote sensing of water harvesting and carbon sequestration by 551 forests in the Taita Hills, Kenya. Taita Research Station of the University of Helsinki is acknowledged 552 for logistical support. Research permit NCST/RCD/17/012/33 for Taita Research Station from 553 National Council for Science and Technology of Kenya is greatly acknowledged.

\section{References}


560 Aerts, R., Thijs, K.W., Lehouck, V., Beentje, H., Bytebier, B., Matthysen, E., Gulinck, H., Lens, L., 561 Muys, B., 2011. Woody plant communities of isolated Afromontane cloud forests in Taita Hills, 562 Kenya. Plant Ecol 212, 639-649.

563 Al-Shami, S.A., Heino, J., Salmah, M.R.C., Abu Hassan, A., Suhaila, A.H., Madrus, M.R., 2013. 564 Drivers of beta diversity of macroinvertebrate communities in tropical forest streams. Freshwater 565 Biol 58, 1126-1137.

566 Alcantara-Ayala, I., Esteban-Chavez, O., Parrot, J.F., 2006. Landsliding related to land-cover 567 change: A diachronic analysis of hillslope instability distribution in the Sierra Norte, Puebla, 568 Mexico. Catena 65, 152-165.

569 Allan, D.J., Castillo, M.M., 2007. Stream Ecology: Structure and function of running waters, 2nd 570 ed. Springer, P.O.Box 173300 AA Dordrecht The Netherlands.

571 Anderson, M.J., 2006. Distance-based tests for homogeneity of multivariate dispersions. Biometrics $57262,245-253$.

573 574 575 576 577 578 579 580 581 582 583 584 585 586 587

Anderson, M.J., Ellingsen, K.E., McArdle, B.H., 2006. Multivariate dispersion as a measure of beta diversity. Ecol Lett 9, 683-693.

Astorga, A., Death, R., Death, F., Paavola, R., Chakraborty, M., Muotka, T., 2014. Habitat heterogeneity drives the geographical distribution of beta diversity: the case of New Zealand stream invertebrates. Ecol Evol 4, 2693-2702.

Astorga, A., Oksanen, J., Luoto, M., Soininen, J., Virtanen, R., Muotka, T., 2012. Distance decay of similarity in freshwater communities: do macro- and microorganisms follow the same rules? Global Ecol Biogeogr 21, 365-375.

Baselga, A., Orme, D., Villeger, S., De Bortoli, J., Leprieur, F., 2017. Partitioning Beta Diversity into Turnover and Nestedness Components. R package 'betapart' version 1.4-1.

Beentje, H.J., Ndiang'ui, N., 1988. An ecological and floristic study of the forests of the Taita Hills, Kenya. Utafiti 1, 23-66.

Beisner, B.E., Peres-Neto, P.R., Lindstrom, E.S., Barnett, A., Longhi, M.L., 2006. The role of environmental and spatial processes in structuring lake communities from bacteria to fish. Ecology 87, 2985-2991.

Bellinger, B.J., Cocquyt, C., O'Reilly, C.M., 2006. Benthic diatoms as indicators of eutrophication in tropical streams. Hydrobiologia 573, 75-87.

Benz, U.C., Hofmann, P., Willhauck, G., Lingenfelder, I., Heynen, M., 2004. Multi-resolution, object-oriented fuzzy analysis of remote sensing data for GIS-ready information. Isprs J Photogramm 58, 239-258.

Bere, T., 2014. Ecological preferences of benthic diatoms in a tropical river system in Sao CarlosSP, Brazil. Trop Ecol 55, 47-61.

Bere, T., Tundisi, J.G., 2011. Influence of land-use patterns on benthic diatom communities and water quality in the tropical Monjolinho hydrological basin, Sao Carlos-SP, Brazil. Water Sa 37, 93-102. 
598 Besemer, K., Singer, G., Quince, C., Bertuzzo, E., Sloan, W., Battin, T.J., 2013. Headwaters are 599 critical reservoirs of microbial diversity for fluvial networks. P Roy Soc B-Biol Sci 280.

600 Biggs, B.J.F., 1995. The Contribution of Flood Disturbance, Catchment Geology and Land-Use to 601 the Habitat Template of Periphyton in Stream Ecosystems. Freshwater Biol 33, 419-438.

602 Bojorge-Garcia, M., Carmona, J., Ramirez, R., 2014. Species richness and diversity of benthic 603 diatom communities in tropical mountain streams of Mexico. Inland Waters 4, 279-292.

604 Breiman, L., 2001. Random forests. Mach Learn 45, 5-32.

605

606

607

608

609

610

611

612

613

614

615

616

617

618

619

620

621

622

623

624

625

626

627

628

629

630

631

632

633

634

635

636

Brink, A.B., Bodart, C., Brodsky, L., Defourney, P., Ernst, C., Donney, F., Lupi, A., Tuckova, K., 2014. Anthropogenic pressure in East Africa-Monitoring 20 years of land cover changes by means of medium resolution satellite data. Int J Appl Earth Obs 28, 60-69.

Carpenter, K.D., Waite, I.R., 2000. Relations of habitat-specific algal assemblages to land use and water chemistry in the Willamette Basin, Oregon. Environ Monit Assess 64, 247-257.

Clark, B.J.F., Pellikka, P.K.E., 2009. Landscape analysis using multi-scale segmentation and objectoriented classification, in: Röder, A., Hill, J. (Eds.), Recent Advances in Remote Sensing and Geoinformation Processing for Land Degradation Assessment. CRS Press, Taylor \& Francis Group, Boca Raton, FL 33487-2742, USA, pp. 323-341.

Colwell, R.K., Coddington, J.A., 1994. Estimating Terrestrial Biodiversity through Extrapolation. Philos T Roy Soc B 345, 101-118.

Comte, J., Lovejoy, C., Crevecoeur, S., Vincent, W.F., 2016. Co-occurrence patterns in aquatic bacterial communities across changing permafrost landscapes. Biogeosciences 13, 175-190.

Concoran, E., Nellermann, C., Baker, E., Bos. R., Osborn, D., Savelli, H.E., 2010. Sick water? The central role of wastewater management in sustainable development. A rapid response assessment. United Nations Environment Programme, UN-HABITAT, GRID-Arendal, Norway.

Crump, B.C., Adams, H.E., Hobbie, J.E., Kling, G.W., 2007. Biogeography of bacterioplankton in lakes and streams of an arctic tundra catchment. Ecology 88, 1365-1378.

da Silva, P.G., Hernandez, M.I.M., 2014. Local and Regional Effects on Community Structure of Dung Beetles in a Mainland-Island Scenario. Plos One 9.

Dormann, C.F., Elith, J., Bacher, S., Buchmann, C., Carl, G., Carre, G., Marquez, J.R.G., Gruber, B., Lafourcade, B., Leitao, P.J., Munkemuller, T., McClean, C., Osborne, P.E., Reineking, B., Schroder, B., Skidmore, A.K., Zurell, D., Lautenbach, S., 2013. Collinearity: a review of methods to deal with it and a simulation study evaluating their performance. Ecography 36, 27-46.

Dormann, C.F., Schweiger, O., Augenstein, I., Bailey, D., Billeter, R., de Blust, G., DeFilippi, R., Frenzel, M., Hendrickx, F., Herzog, F., Klotz, S., Liira, J., Maelfait, J.P., Schmidt, T., Speelmans, M., van Wingerden, W.K.R.E., Zobel, M., 2007. Effects of landscape structure and land-use intensity on similarity of plant and animal communities. Global Ecol Biogeogr 16, 774-787.

Dray, S., Guillaume, B., Borcard, D., Guenard, G., Jombart, T., Larocque, G., Legendre, P., Madi, M., Wagner, H.H., 2017. Package 'adespatial'. Multivariate multiscale spatial analysis.

Elith, J., Leathwick, J.R., Hastie, T., 2008. A working guide to boosted regression trees. J Anim Ecol 77, 802-813. 
637 Erdogan, H.E., Pellikka, P.K.E., Clark, B., 2011. Modelling the impact of land-cover change on 638 potential soil loss in the Taita Hills, Kenya, between 1987 and 2003 using remote-sensing and 639 geospatial data. Int J Remote Sens 32, 5919-5945.

640 ESA, European Spatial Agency, 2015. Sentinel-2 user handbook. ESA Standard Document. 64.

641 Finn, D.S., Bonada, N., Murria, C., Hughes, J.M., 2011. Small but mighty: headwaters are vital to 642 stream network biodiversity at two levels of organization. J N Am Benthol Soc 30, 963-980.

643 Gaston, K.J., 2000. Global patterns in biodiversity. Nature 405, 220-227.

644 Gereau, R.E., Taylor, C.M., Luke, W.R.Q., 2006. Endemic plant species of the Eastern Arc 645 Mountains of Kenya and Tanzania: analysis and refinement of distributional patterns. In: Taxonomy 646 and Ecology of African Plants, their Conservation and Sustainable Use., in: Ghazanfar, S.A., 647 Beentje, H.J. (Eds.), Proceedings of the 17th AETFAT Congress, Addis Ababa, Ethiopia. Royal 648 Botanic Gardens, Kew, pp. 267-277.

649 Giraudoux, P., 2015. Data Analysis in Ecology. R package version 1.6.3.

650 Google Earth 7.1.8.3036...

651 Gothe, E., Angeler, D.G., Gottschalk, S., Lofgren, S., Sandin, L., 2013. The Influence of 652 Environmental, Biotic and Spatial Factors on Diatom Metacommunity Structure in Swedish 653 Headwater Streams. Plos One 8.

654 Grant, E.H.C., Lowe, W.H., Fagan, W.F., 2007. Living in the branches: population dynamics and 655 ecological processes in dendritic networks. Ecol Lett 10, 165-175.

656 Green, J.L., Holmes, A.J., Westoby, M., Oliver, I., Briscoe, D., Dangerfield, M., Gillings, M., 657 Beattie, A.J., 2004. Spatial scaling of microbial eukaryote diversity. Nature 432, 747-750.

658 Gutierrez-Canovas, C., Millan, A., Velasco, J., Vaughan, I.P., Ormerod, S.J., 2013. Contrasting 659 effects of natural and anthropogenic stressors on beta diversity in river organisms. Global Ecol 660 Biogeogr 22, 796-805.

661 Heino, J., Bini, L.M., Andersson, J., Bergsten, J., Bjelke, U., Johansson, F., 2017. Unravelling the 662 correlates of species richness and ecological uniqueness in a metacommunity of urban pond insects. 663 Ecol Indic 73, 422-431.

664 Heino, J., Bini, L.M., Karjalainen, S.M., Mykra, H., Soininen, J., Vieira, L.C.G., Diniz, J.A.F., 665 2010. Geographical patterns of micro-organismal community structure: are diatoms ubiquitously 666 distributed across boreal streams? Oikos 119, 129-137.

667 Heino, J., Gronroos, M., Soininen, J., Virtanen, R., Muotka, T., 2012. Context dependency and 668 metacommunity structuring in boreal headwater streams. Oikos 121, 537-544.

669 Heino, J., Tolkkinen, M., Pirttila, A.M., Aisala, H., Mykra, H., 2014. Microbial diversity and 670 community-environment relationships in boreal streams. J Biogeogr 41, 2234-2244.

671 Hijmans, R.J.P., S.; Leathwick, J.; Elith, J., 2015. Dismo: Species Distrubution Modelling. R 672 package version 1.0-12.

673 Hill, B.H., Herlihy, A.T., Kaufmann, P.R., Stevenson, R.J., McCormick, F.H., Johnson, C.B., 2000. 674 Use of periphyton assemblage data as an index of biotic integrity. J N Am Benthol Soc 19, 50-67. 
675 Hillebrand, H., 2004. On the generality of the latitudinal diversity gradient. Am Nat 163, 192-211.

676 Hillebrand, H., Azovsky, A.I., 2001. Body size determines the strength of the latitudinal diversity 677 gradient. Ecography 24, 251-256.

678 Hohenthal, J., Owidi, E., Minoia, P., Pellikka, P., 2015. Local assessment of changes in water679 related ecosystem services and their management: DPASER conceptual model and its application in 680 Taita Hills, Kenya. International Journal of Biodiversity Science, Ecosystem Services \& 681 Management 11, 225-238.

682 IUCN, 2009. Wildlife in a changing world and analysis of the 2008 IUCN Red List of Threatened 683 Species, Vié, J.-C., Hilton-Taylor, C., Stuart, S.N. (Eds.), Gland, Switzerland.

684 Januchowski-Hartley, S.R., Pearson, R.G., Puschendorf, R., Rayner, T., 2011. Fresh Waters and 685 Fish Diversity: Distribution, Protection and Disturbance in Tropical Australia. Plos One 6.

686 Jyrkankallio-Mikkola, J., Heino, J., Soininen, J., 2016. Beta diversity of stream diatoms at two 687 hierarchical spatial scales: implications for biomonitoring. Freshwater Biol 61, 239-250.

688 Jyrkankallio-Mikkola, J., Meier, S., Heino, J., Laamanen, T., Pajunen, V., Tolonen, K.T., 689 Tolkkinen, M., Soininen, J., 2017 Disentangling multi-scale environmental effects on stream 690 microbial communities. J Biogeogr 44, 1512-1523, doi:10.1111/jbi.13002

691 Krammer, K., Lange-Bertalot, H., 1986-1991. Bacillariophyceae. Süßwasserflora von Mitteleuropa 692 1:4, 2. Fischer, Stuttgart.

693 Lawton, J.H., 1999. Are there general laws in ecology? Oikos 84, 177-192.

694 Legendre, P., Borcard, D., Peres-Neto, P.R., 2005. Analyzing beta diversity: Partitioning the spatial 695 variation of community composition data. Ecol Monogr 75, 435-450.

696 Legendre, P., De Caceres, M., 2013. Beta diversity as the variance of community data: dissimilarity 697 coefficients and partitioning. Ecol Lett 16, 951-963.

698 Legendre, P., Gallagher, E.D., 2001. Ecologically meaningful transformations for ordination of 699 species data. Oecologia 129, 271-280.

700 Legendre, P., Legendre, L., 2012. Numerical ecology, 3 ed. Elsevier, Amsterdam.

701 Lindstrom, E.S., Langenheder, S., 2012. Local and regional factors influencing bacterial community 702 assembly. Env Microbiol Rep 4, 1-9.

703 Lopes, P.M., Bini, L.M., Declerck, S.A.J., Farjalla, V.F., Vieira, L.C.G., Bonecker, C.C., Lansac704 Toha, F.A., Esteves, F.A., Bozelli, R.L., 2014. Correlates of Zooplankton Beta Diversity in Tropical 705 Lake Systems. Plos One 9.

706 Lovett, J.C., Wasser, S.K., 1993. Biogeography and Ecology of the Rainforests of Eastern Africa. 707 Cambridge University Press, Cambridge.

708 Maloufi, S., Catherine, A., Mouillot, D., Louvard, C., Coute, A., Bernard, C., Troussellier, M., 709 2016. Environmental heterogeneity among lakes promotes hyper -diversity across phytoplankton 710 communities. Freshwater Biol 61, 633-645. 
Mangadze, T., Bere, T., Mwedzi, T., 2015. Epilithic diatom flora in contrasting land-use settings in tropical streams, Manyame Catchment, Zimbabwe. Hydrobiologia 753, 163-173.

Medley, K.E., J.K. Maingi, 2014. Biogeographic patterns of forest diversity at Mt. Kasigau, Kenya. J East Af Nat Hist Soc Natl Mus 103: 1-24.

Meyer, J.L., Strayer, D.L., Wallace, J.B., Eggert, S.L., Helfman, G.S., Leonard, N.E., 2007. The contribution of headwater streams to biodiversity in river networks. J Am Water Resour As 43, 86103.

Nabout, J.C., Siqueira, T., Bini, L.M., Nogueira, I.D., 2009. No evidence for environmental and spatial processes in structuring phytoplankton communities. Acta Oecol 35, 720-726.

Oksanen, J., Blanchet, F.G., Kindt, R., Legendre, P., Minchin, P.R., O'Hara, R.B., Simpson, G.L., Solymos, P., Stevens, M.H.H., Wagner, H., 2015. Vegan: Community Ecology Package. R package version 2.3.2.

Omoro, L.M.A., Starr, M., Pellikka, P.K.E., 2013. Tree biomass and soil carbon stocks in indigenous forests in comparison to plantations of exotic species in the Taita Hills of Kenya. Silva Fenn 47.

Pajunen, V., Luoto, M., Soininen, J., 2016. Climate is an important driver for stream diatom distributions. Global Ecol Biogeogr 25, 198-206.

Pajunen, V., Luoto, M., Soininen, J. 2017. Unravelling direct and indirect effects of hierarchical factors driving microbial stream communities. J Biogeogr, In press.

Paller, M.H., 1994. Relationships between Fish Assemblage Structure and Stream Order in SouthCarolina Coastal-Plain Streams. T Am Fish Soc 123, 150-161.

Palmer, M.W., 1990. The Estimation of Species Richness by Extrapolation. Ecology 71, 11951198.

Passy, S.I., 2010. A distinct latitudinal gradient of diatom diversity is linked to resource supply. Ecology 91, 36-41.

Pellikka, P.K.E., Clark, B.J.F., Gonsamo-Gosa, A., Himberg, N., Hurskainen, P., Maeda, E.E., Mwang'ombe, L.M.A., Siljander, M., 2013. Agricultural expansion and its consequences in the Taita Hills, Kenya, in: Paron, P., Olago, D., Thine Omuto, C. (Eds.), Kenya: a Natural Outlook : Geo-Environmental Resources and Hazards . Developments in Earth Surface Processes. NorthHolland Pub.Co, Amsterdam, The Netherlands, pp. 165-179.

Pellikka, P.K.E., Lotjonen, M., Sijander, M., Lens, L., 2009. Airborne remote sensing of spatiotemporal change (1955-2004) in indigenous and exotic forest cover in the Taita Hills, Kenya. Int J Appl Earth Obs 11, 221-232.

Pellikka, P.K.E., Heikinheimo, V., Hietanen, J., Schäfer, E., Siljander, M., Heiskanen, J.. Assessment of the impact of land cover change on aboveground carbon stocks using airborne lidar data and satellite imagery in Taita Hills, Kenya. Submitted manuscript

Piano, E., Falasco, E., Bona, F., 2017 How does water scarcity affect spatial and temporal patterns of diatom community assemblages in Mediterranean streams? Freshwater Biol 62:1276-1287, DOI: 10.1111/fwb.12944. 
750 Pimm, S.L., Russell, G.J., Gittleman, J.L., Brooks, T.M., 1995. The future of biodiversity. Science $751269,347-350$.

752 753 754 755 756 757 758 759 760 761 762 763 764 765 766 767 768 769 770 771 772 773 774 775 776

Platts, P.J., Burgess, N.D., Gereau, R.E., Lovett, J.C., Marshall, A.R., McClean, C.J., Pellikka, P.K.E., Swetnam, R.D., Marchant, R., 2011. Delimiting tropical mountain ecoregions for conservation. Environ Conserv 38, 312-324.

Potapova, M.G., Charles, D.F., 2002. Benthic diatoms in USA rivers: distributions along spatial and environmental gradients. J Biogeogr 29, 167-187.

Qiao, X.J., Li, Q.X., Jiang, Q.H., Lu, J.M., Franklin, S., Tang, Z.Y., Wang, Q.G., Zhang, J.X., Lu, Z.J., Bao, D.C., Guo, Y.L., Liu, H.B., Xu, Y.Z., Jiang, M.X., 2015. Beta diversity determinants in Badagongshan, a subtropical forest in central China. Sci Rep-Uk 5.

Reich, P.B., Oleksyn, J., 2004. Global patterns of plant leaf N and P in relation to temperature and latitude. P Natl Acad Sci USA 101, 11001-11006.

Ridgeway, G., 2013. Generalized boosted regression models. R package version 2.1.1.

Rikkinen, J., Laine, T., Pellikka, P. 2015. Water's Journey (A documentary film). Wildheart Productions Oy. Taita Research Station of the University of Helsinki.

Rosenzweig, M.L., 1995. Species Diversity in Space and Time. Cambridge University Press, Cambridge.

Salinas, H.F.O., Alder, V.A., Puig, A., Boltovskoy, D., 2015. Latitudinal diversity patterns of diatoms in the Southwestern Atlantic and Antarctic waters. J Plankton Res 37, 659-665.

Schafer, E., Heiskanen, J., Heikinheimo, V., Pellikka, P., 2016. Mapping tree species diversity of a tropical montane forest by unsupervised clustering of airborne imaging spectroscopy data. Ecol Indic 64, 49-58.

Sherwood, A.R., Rintoul, T.L., Muller, K.M., Sheath, R.G., 2000. Seasonality and distribution of epilithic diatoms, macroalgae and macrophytes in a spring-fed stream system in Ontario, Canada. Hydrobiologia 435, 143-152.

Shmida, A., Wilson, M.V., 1985. Biological Determinants of Species-Diversity. J Biogeogr 12, 120 .

Socolar, J.B., Gilroy, J.J., Kunin, W.E., Edwards, D.P., 2016. How Should Beta-Diversity Inform Biodiversity Conservation? Trends Ecol Evol 31, 67-80.

Soininen, J., 2007. Environmental and spatial control of freshwater diatoms - A review. Diatom Res 22, 473-490.

Soininen, J., Bartels, P., Heino, J., Luoto, M., Hillebrand, H., 2015. Toward More Integrated Ecosystem Research in Aquatic and Terrestrial Environments. Bioscience 65, 174-182.

Soininen, J., Jamoneau, A., Rosebery, J., Passy, S.I., 2016. Global patterns and drivers of species and trait composition in diatoms. Global Ecol Biogeogr 25, 940-950.

Soininen, J., Paavola, R., Muotka, T., 2004. Benthic diatom communities in boreal streams: community structure in relation to environmental and spatial gradients. Ecography 27, 330-342. 
Stam, A., Enroth, J., Malombe, I., Pellikka, P., Rikkinen, J., 2017. Experimental transplants reveal strong environmental effects on the growth on non-vascular epiphytes in Afromontane Forests. Biotropica, In press

Starhler, A.N., 1957 Quantitative Analysis of Watershed Geomorphology. Transactions, American Geophysical, Union 38:6.

Stenger-Kovacs, C., Toth, L., Toth, F., Hajnal, E., Padisak, J., 2014. Stream order-dependent diversity metrics of epilithic diatom assemblages. Hydrobiologia 721, 67-75.

Strayer, D.L., Dudgeon, D., 2010. Freshwater biodiversity conservation: recent progress and future challenges. J N Am Benthol Soc 29, 344-358.

Taylor, J.C., Harding, W.R., Archibald, C.G.M., 2007. An illustrated guide to some common diatom species from South Africa, Development of a Diatom Assessment Protocol (DAP) for River Health Assessment. Water Research Comission, Republic of South Africa, p. 178.

Telford, R.J., Vandvik, V., Birks, H.J.B., 2006. Dispersal limitations matter for microbial morphospecies. Science 312, 1015-1015.

Thomas, C.D., Cameron, A., Green, R.E., Bakkenes, M., Beaumont, L.J., Collingham, Y.C., Erasmus, B.F.N., de Siqueira, M.F., Grainger, A., Hannah, L., Hughes, L., Huntley, B., van Jaarsveld, A.S., Midgley, G.F., Miles, L., Ortega-Huerta, M.A., Peterson, A.T., Phillips, O.L., Williams, S.E., 2004. Extinction risk from climate change. Nature 427, 145-148.

Tonkin, J.D., Arimoro, F.O., Haase, P., 2016. Exploring stream communities in a tropical biodiversity hotspot: biodiversity, regional occupancy, niche characteristics and environmental correlates. Biodivers Conserv 25, 975-993.

UNESCO, 2009. World Water Assessment Programme, Water in a Changing World. The United Nations World Water Development Report 3, UNESCO.

US- Environmental Protection Agency, 2000. The quality of Our Nation's Waters, EPA-841-R-02001, US EPA, Wasington DC.

Wang, Y.K., Stevenson, R.J., Metzmeier, L., 2005. Development and evaluation of a diatom-based index of Biotic Integrity for the Interior Plateau Ecoregion, USA. J N Am Benthol Soc 24, 9901008.

Vannote, R.L.M., G.W.; Cummins, K.W.; Sedell, J.R.; Cushing, C.E., 1980. The river continuum concept. Can J Fish Aquat Sci 37, 130-137.

Wei, T., Simko, V., 2016. Corrplot: Visualization of a Correlation Matrix. R package version 0.77.

Wentworth, C.K., 1922. A Scale of Grade and Class Terms for Clastic Sediments. The Journal of Geology 30, 377-392.

Verleyen, E., Vyverman, W., Sterken, M., Hodgson, D.A., De Wever, A., Juggins, S., Van de Vijver, B., Jones, V.J., Vanormelingen, P., Roberts, D., Flower, R., Kilroy, C., Souffreau, C., Sabbe, K., 2009. The importance of dispersal related and local factors in shaping the taxonomic structure of diatom metacommunities. Oikos 118, 1239-1249.

Wetzel, C.E., Bicudo, D.D., Ector, L., Lobo, E.A., Soininen, J., Landeiro, V.L., Bini, L.M., 2012. Distance Decay of Similarity in Neotropical Diatom Communities. Plos One 7. 
826 Wiens, J.J., 2016. Climate-Related Local Extinctions Are Already Widespread among Plant and 827 Animal Species. Plos Biol 14.

828 Williams-Linera, G., 2002. Tree species richness complementarity, disturbance and fragmentation 829 in a Mexican tropical montane cloud forest. Biodivers Conserv 11, 1825-1843.

830 Vinson, M.R., Hawkins, C.P., 1998. Biodiversity of stream insects: Variation at local, basin, and 831 regional scales. Annu Rev Entomol 43, 271-293.

832 Vorosmarty, C.J., McIntyre, P.B., Gessner, M.O., Dudgeon, D., Prusevich, A., Green, P., Glidden, 833 S., Bunn, S.E., Sullivan, C.A., Liermann, C.R., Davies, P.M., 2010. Global threats to human water 834 security and river biodiversity (vol 467, pg 555, 2010). Nature 468, 334-334.

835 Zeglin, L.H., 2015. Stream microbial diversity in response to environmental changes: review and 836 synthesis of existing research. Front Microbiol 6.

837 Zorzal-Almeida, S., Bini, L.M., Bicudo, D.C., 2017 Beta diversity of diatoms is driven by 838 environmental heterogeneity, spatial extent and productivity. Hydrobiologia, In press, 839 doi:10.1007/s10750-017-3117-3 
841 Appendix A List of measured environmental and land use variables (average values and ranges). * removed from multivariate analysis due to low concentrations, **removed from further analysis to avoid $100 \%$ coverage of the 843 variable group.

\begin{tabular}{|c|c|c|c|}
\hline \multicolumn{2}{|r|}{ Variable } & \multirow{2}{*}{$\begin{array}{c}\text { Mean values } \\
1293.00\end{array}$} & \multirow{2}{*}{$\begin{array}{c}\text { Range } \\
(713.00-1929.00)\end{array}$} \\
\hline Environmental & Elevation (m) & & \\
\hline variables $(n=67)$ & $\mathrm{pH}$ & 7.90 & $(6.90-8.89)$ \\
\hline & Conductivity $\left(\mathrm{mSm}^{-1}\right)$ & 120.28 & $(15.10-408.70)$ \\
\hline & Colour (Pt mgl-1 $)$ & 9.02 & $(0-50)$ \\
\hline & Total $\mathrm{P}\left(\mu \mathrm{gl}^{-1}\right)^{*}$ & 14.46 & $(<10.00-69.00)$ \\
\hline & Total N $\left(\mu \mathrm{gl}^{-1}\right)$ & 698.06 & $(150.00-2380.00)$ \\
\hline & Shading (\%) & 40.11 & $(0.00-96.30)$ \\
\hline & Depth (m) & 0.07 & $(0.01-0.23)$ \\
\hline & Width $(\mathrm{cm})$ & 148.01 & $(17.00-1310.00)$ \\
\hline & Velocity $\left(\mathrm{ms}^{-1}\right)$ & 0.17 & $(0.02-0.73)$ \\
\hline & Sand (\%) & 46.17 & $(0.00-100.00)$ \\
\hline & Gravel (\%) & 5.29 & $(0.00-46.50)$ \\
\hline & Pebble (\%) & 4.66 & $(0.00-35.00)$ \\
\hline & Cobble (\%) & 7.34 & $(0.00-49.50)$ \\
\hline & Boulders (\%) & 9.11 & $(0.00-64.00)$ \\
\hline & Moss $(\%)^{* *}$ & 5.73 & $(0.00-90.00)$ \\
\hline Land use & Catchment area $\left(\mathrm{km}^{2}\right)$ & 2.32 & $(0.14-25.58)$ \\
\hline variables $(n=39)$ & Cropland (\%) & 38.00 & $(0.00-77.76)$ \\
\hline & Shrubland (\%) & 1.93 & $(0.00-23.81)$ \\
\hline & Thicket (\%) & 5.75 & $(0.00-39.14)$ \\
\hline & Woodland (\%) & 21.10 & $(0.00-51.42)$ \\
\hline & Plantation forest (\%) & 15.75 & $(0.00-41.56)$ \\
\hline & Broadleaved forest (\%) & 14.70 & $(0.00-93.00)$ \\
\hline & Bare soil and built areas (\%) & 1.10 & $(0.00-14.00)$ \\
\hline & Bare rock $(\%)$ & 1.50 & $(0.00-15.60)$ \\
\hline & Water bodies (\%)** & 0.01 & $(0.00-0.41)$ \\
\hline
\end{tabular}




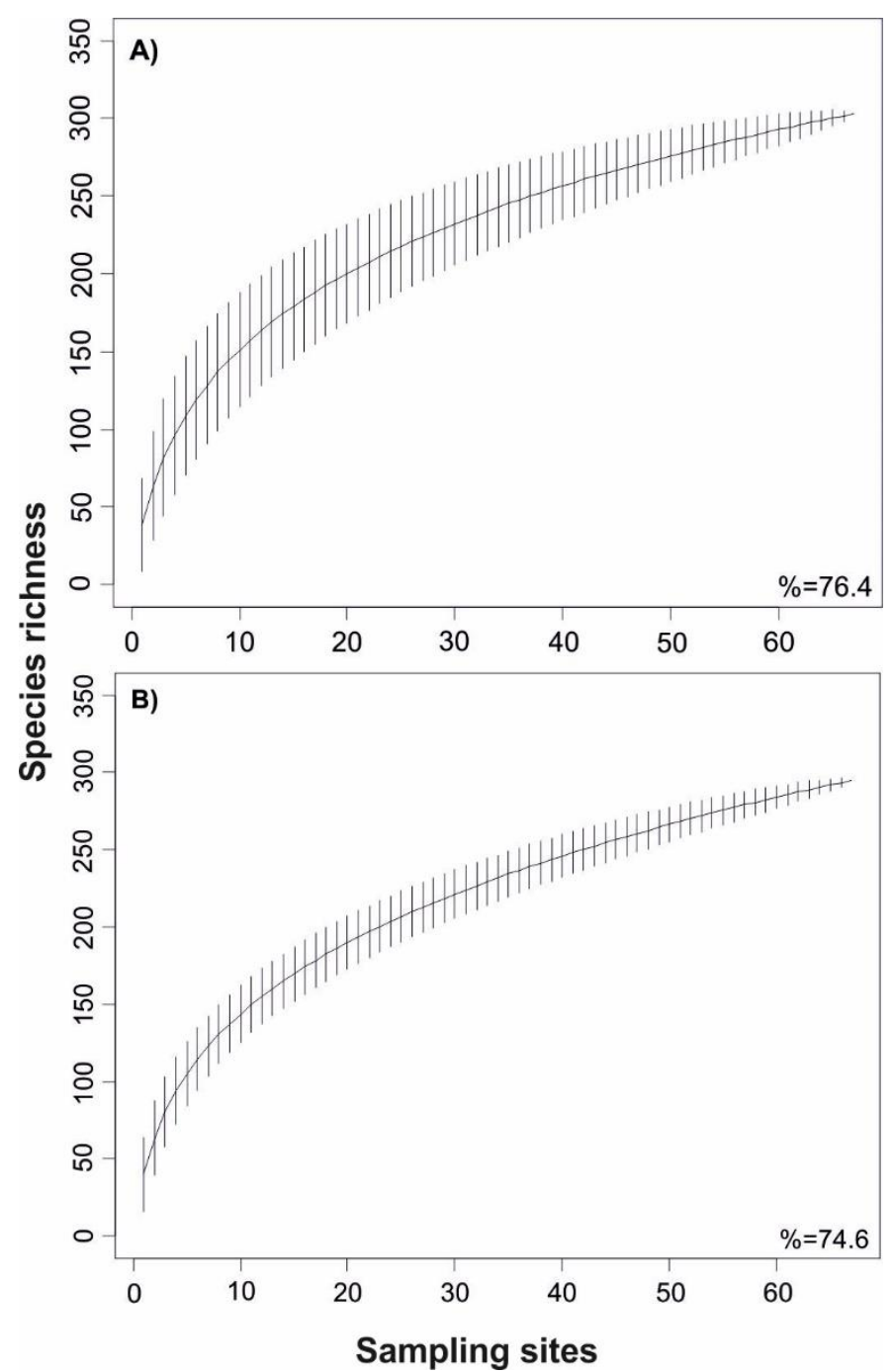

Appendix B Species accumulation curves for A) boreal and B) tropical streams. The proportion of estimated species richness that 67 sampling sites covered is shown on the lower right corner. 

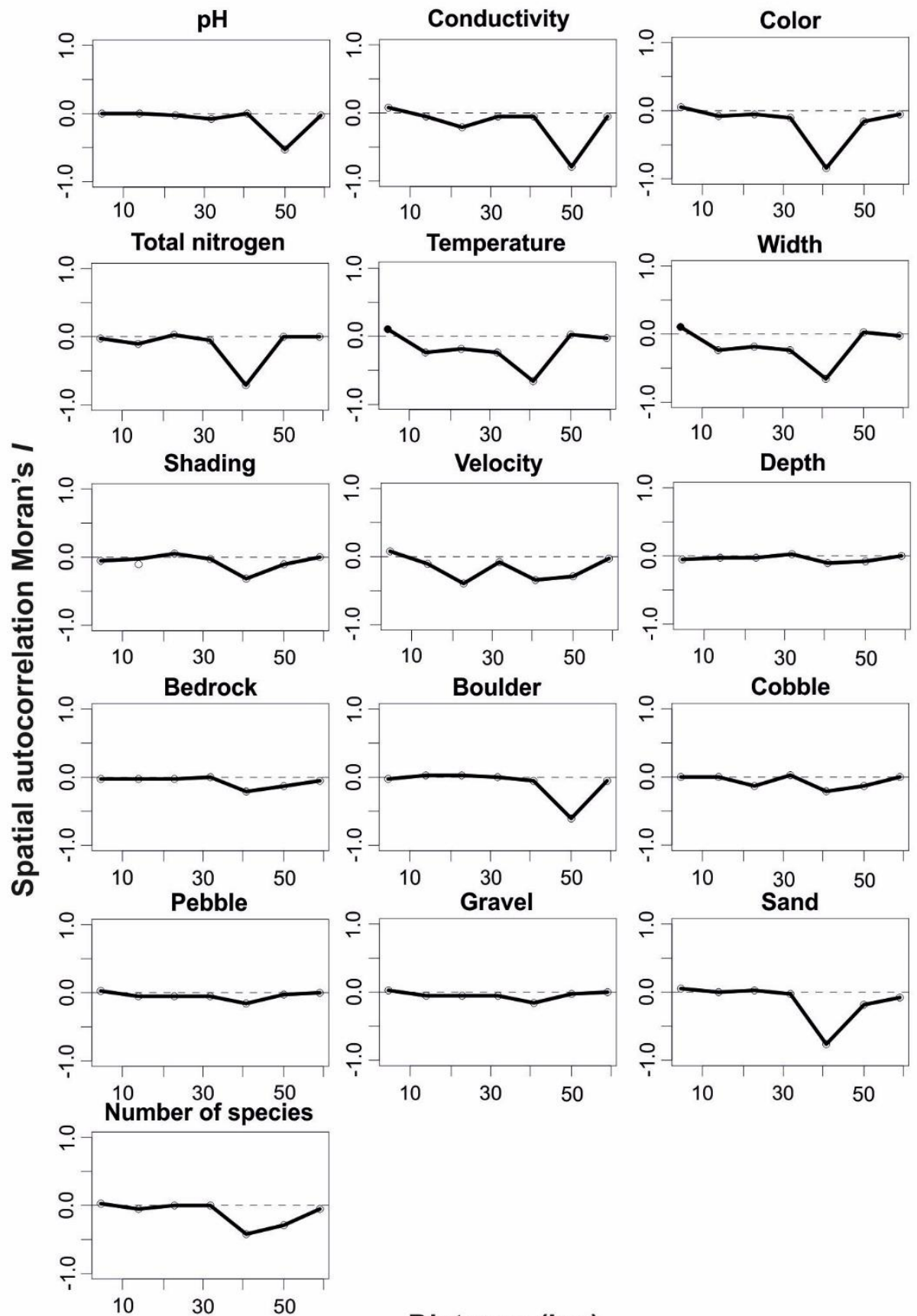

Distance $(\mathrm{km})$

850 Appendix C Moran's I correlogram representing spatial autocorrelation for 15 environmental variables and diatom species richness. Black filled circles mark significant values of Moran's I and represent significant positive 

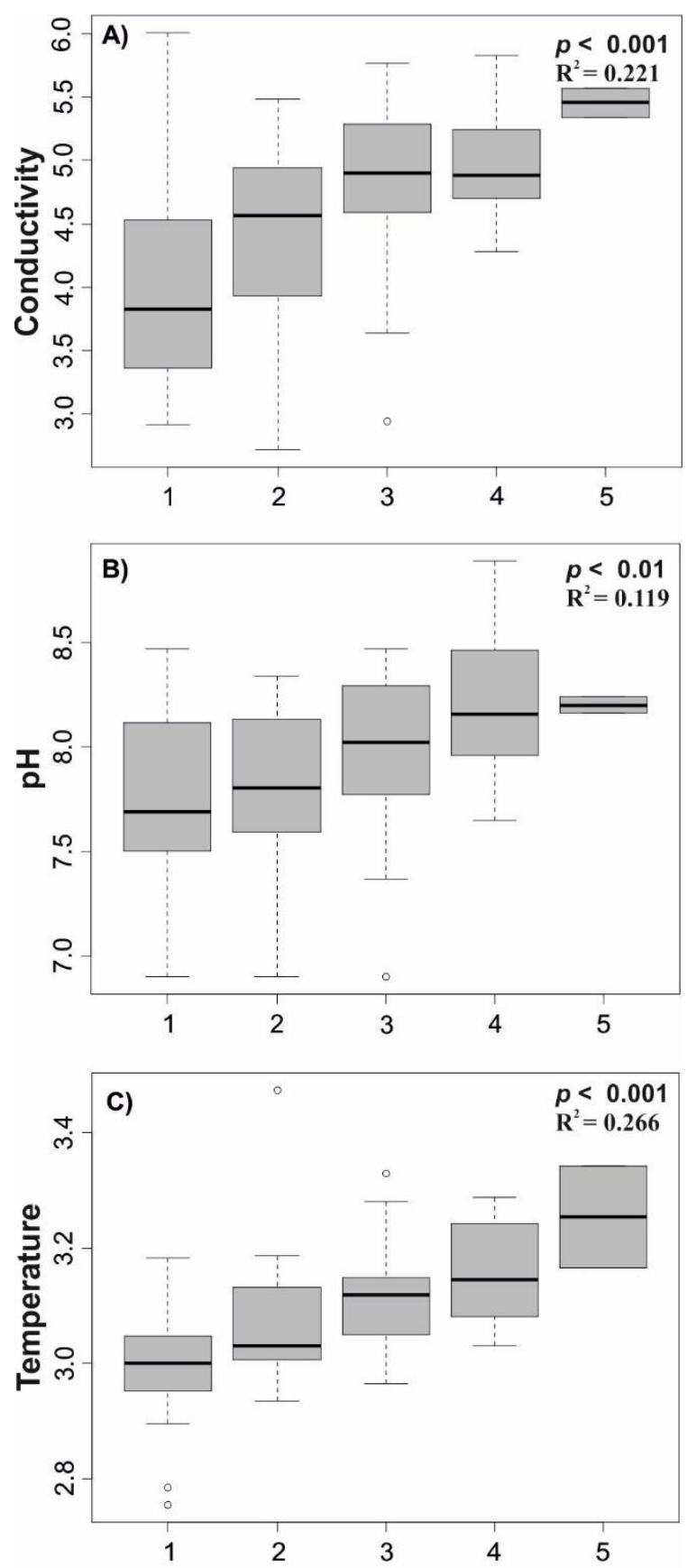

853

Stream order

854 Appendix D Boxplots representing the relationship of A) $\log$ transformed conductivity, B) pH, C) log transformed 855 temperature and stream order. 